\title{
Selectivity of Transport Processes in Ion-Exchange Membranes: Relationship with the Structure and Methods for Its Improvement
}

\author{
Irina Stenina ${ }^{1}$, Daniel Golubenko ${ }^{1}$, Victor Nikonenko ${ }^{2} \mathbb{D}$ and Andrey Yaroslavtsev ${ }^{1, *(D)}$ \\ 1 Kurnakov Institute of General and Inorganic Chemistry of the RAS, 119991 Moscow, Russia; \\ stenina@igic.ras.ru (I.S.); xpman2009@yandex.ru (D.G.) \\ 2 Membrane Institute, Kuban State University, 350040 Krasnodar, Russia; v_nikonenko@mail.ru \\ * Correspondence: yaroslav@igic.ras.ru
}

Received: 13 July 2020; Accepted: 30 July 2020; Published: 1 August 2020

check for updates

\begin{abstract}
Nowadays, ion-exchange membranes have numerous applications in water desalination, electrolysis, chemistry, food, health, energy, environment and other fields. All of these applications require high selectivity of ion transfer, i.e., high membrane permselectivity. The transport properties of ion-exchange membranes are determined by their structure, composition and preparation method. For various applications, the selectivity of transfer processes can be characterized by different parameters, for example, by the transport number of counterions (permselectivity in electrodialysis) or by the ratio of ionic conductivity to the permeability of some gases (crossover in fuel cells). However, in most cases there is a correlation: the higher the flux density of the target component through the membrane, the lower the selectivity of the process. This correlation has two aspects: first, it follows from the membrane material properties, often expressed as the trade-off between membrane permeability and permselectivity; and, second, it is due to the concentration polarization phenomenon, which increases with an increase in the applied driving force. In this review, both aspects are considered. Recent research and progress in the membrane selectivity improvement, mainly including a number of approaches as crosslinking, nanoparticle doping, surface modification, and the use of special synthetic methods (e.g., synthesis of grafted membranes or membranes with a fairly rigid three-dimensional matrix) are summarized. These approaches are promising for the ion-exchange membranes synthesis for electrodialysis, alternative energy, and the valuable component extraction from natural or waste-water. Perspectives on future development in this research field are also discussed.
\end{abstract}

Keywords: ion-exchange membranes; functional polymers; selectivity; ionic conductivity; hybrid membranes; grafted membranes

\section{Introduction}

Ion exchange membranes (IEMs) are actively used in modern technologies, including water purification, concentration, electrochemical synthesis, and sensors [1-5]. Their use in fuel cells [6-9], in energy storage and conversion systems, e.g., metal-ion batteries [10-12], reverse electrodialysis [13-15], and redox batteries [16-19] has received the most attention in recent years. There are a number of other technologies in which ion-exchange membranes can also be used. For example, they can successfully compete with porous membranes in the processes of alkenes/alkanes separation [20-24]. Undoubtedly, ionic conductivity plays a dominant role in these applications. Even the above-mentioned alkene transfer proceeds via the a complex with silver ions or protons [23,25-27].

At the same time, the ion separation by membranes never occurs with $100 \%$ selectivity and is usually accompanied by an undesired transfer of molecules or opposite charged ions. Despite the fact 
that these processes proceed to a much less extent, they usually determine the decrease in the efficiency of electrodialysis, fuel cells and other devices based on ion-exchange membranes [16,28-30]. That is why their understanding is so important for numerous membrane technologies.

The selectivity of transport processes in ion-exchange membranes is determined by the structure of their pores and channels [31-34]. As this structure is formed as a result of the self-organization, it is difficult to control but it is the key aspect which allows one to regulate the ion-exchange membrane selectivity. In addition, there are major differences between the morphology of homogeneous and heterogeneous membranes, which lead to a lower selectivity of the latter $[33,35,36]$. Nevertheless, lower cost of heterogeneous membranes determines their widespread use in electrodialysis plants and in a number of other devices $[37,38]$.

Recently, increasing attention has been paid to the separation and processing of complex mixtures, including industrial and domestic wastes, sea water [39-45]. There is every reason to believe that their processing, along with recycling, would determine a major part of production of a number of metals and their compounds [39,46-50]. For the development of such technologies the selectivity between ions with different valences of the same sign (mono- and multivalent) is no less important [51-54]. The processes of their separation have recently been extensively reviewed [55-58]. However, this topic cannot be ignored, and in order to avoid overlapping, in this review, we will consider it briefly, focusing on newer studies in this area.

This review is devoted to the consideration of the selectivity of transport processes in ion-exchange membranes. The membrane structure-selectivity relationship and various methods for selectivity management are discussed. The main attention is paid to the selectivity of transport processes of ions with different charges and ions with neutral molecules.

\section{The Ion Exchange Membrane Structure and Ion Transfer}

Description of the ion-exchange membrane structure should be started from one of the benchmark materials-perfluorosulfonic acid membranes of the Nafion type. Nafion is a random copolymer of tetrafluoroethylene and sulfonyl fluoride vinyl ether $[59,60]$. The first of them forms a hydrophobic perfluorinated backbone, and the second forms a side chain with $-\mathrm{SO}_{3} \mathrm{H}\left(-\mathrm{SO}_{3} \mathrm{M}\right)$ terminal group. The latter are hydrophilic and, as result of self-organization, form clusters, which absorb water from the environment. As a result, there is an extended network of pores $(4-5 \mathrm{~nm}$ in size in a swollen state) and channels filled with water in the membrane. Dissociation of functional groups leads to the formation of an aqueous solution containing dissociated cations [61-64]. On the contrary, fixed $-\mathrm{SO}_{3}{ }^{-}$ ions are localized on the pore walls, giving them a negative charge. Due to the electrostatic interaction, most of the cations are localized in a thin Debye layer near the pore walls, and the so-called electrically neutral solution is located in the pore centers (Figure 1) [32,65]. It is generally accepted that the composition of this electrically neutral solution is close to that of the solution contacting with the membrane. When membranes are used in electrodialysis or reverse electrodialysis, the concentration of contacting solution can be rather high $[16,31,66]$. Moreover, in the central part of the pore, there are a lot of cations and anions which can contribute significantly to the conductivity. On the other hand, it is this pore central part that determines the significant contribution of anionic conductivity, which reduces the selectivity of transport processes. On the contrary, the high field strength in the Debye layer leads to the anion displacement from it, and this layer performs predominantly selective cationic transport [65,67].

When used in fuel cells, the membranes contact with water vapor only. In this case, the electrically neutral solution in their pore centers should be almost pure water with a low cation concentration. This water should freeze near $0{ }^{\circ} \mathrm{C}$. However, due to the small size and high curvature radius, its freezing temperature decreases significantly. Freezing of this water was found in grafted membranes with a very high water uptake and a large pore size [68]. Moreover, its enthalpy value shows that not all water freezes at $0{ }^{\circ} \mathrm{C}$, and about 20 remaining molecules per functional group gradually freeze 
during further cooling [69]. The water uptake of most ion-exchange membranes is less, therefore, phase transformations are usually not observed near $0{ }^{\circ} \mathrm{C}$.

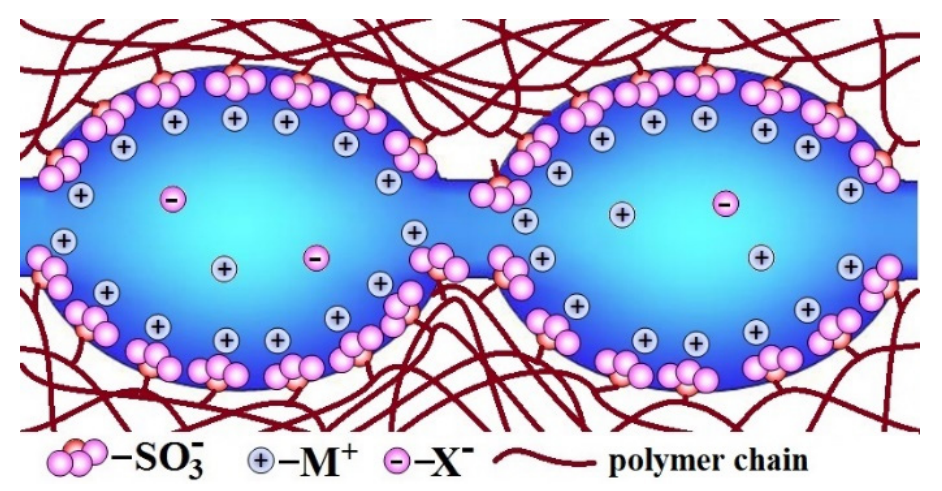

Figure 1. The scheme of pores and channels structure in the ion-exchange membranes (redrawn from [62]).

The water freezing in perfluorinated Nafion membranes, the water uptake of which is usually much less, has been studied in detail. The authors of $[60,70]$ constructed a phase diagram for these membranes at subzero temperatures, from which one can conclude that water freezing near $0{ }^{\circ} \mathrm{C}$ is possible for the water uptake of about 20-30 molecules per $-\mathrm{SO}_{3} \mathrm{H}$ group. Mendil-Jakani et al. [71] estimated this water uptake as 50 molecules per functional group. Water in the Nafion membrane pores usually freezes only at subzero temperatures. Most researchers divided this water into bound water, as these water molecules do not freeze due to electrostatic interactions, and free water that have been observed to be freezable $[60,72-75]$. However, as the temperature decreases, their ratio changes significantly due to the freezing of water occupying the outer solvating shells of $\mathrm{H}_{3} \mathrm{O}^{+}$ions $[70,72,73]$. With a water uptake of four or less per functional group, water freezing is not observed at all [60]. This corresponds to the formation of a stable $\mathrm{H}_{9} \mathrm{O}_{4}{ }^{+}$ion. From the plot of total water vs. free water, Kusoglu et al. [60] estimated amount of non-freezable water as 4.75 molecules per proton of $-\mathrm{SO}_{3} \mathrm{H}$ group. This amount depends substantially on the nature of counterions in the membrane. Some studies revealed that deep cooling of membranes with low water uptake results in glass-transition and desorption of freezing water [71,76].

The higher the water uptake of membranes, the larger the size of pores and channels, which limit ion mobility and conductivity [77-80] (Figure 2a). These channels are similar to the bottlenecks of transport channels in solid electrolyte. Therefore, the conductivity of ion-exchange membranes increases with increasing water uptake. At the same time, the water uptake increases primarily due to an increase in the volume of the electrically neutral solution in the pore centers (Figure 2b). It is where coions, non-polar and low-polar molecules, e.g., molecules of gases that feed fuel cell, are localized. Since the ion flux is determined by the product of the charge carrier concentration and their diffusion coefficient, the rate of non-selective transfer also increases rapidly with increasing water uptake. Thus, the membrane conductivity improvement is most often accompanied by increase in undesirable transfer of coions and nonpolar molecules that decreases the membrane selectivity [81-84]. This relationship will be addressed in detail below. This correlation takes place in the case of not only ion-exchange membranes, but also other types of membranes. As indicated by Park et al. [83], all synthetic membranes exhibit a trade-off between permeability/conductivity (the rate of transfer of molecules and ions through a membrane material) and permselectivity (the ability to separate the target component from the feed solution): the higher membrane permeability, the lower permselectivity, and vice versa. For example, the well-known Robeson diagram illustrates this correlation for gas separation membranes [85-90]. 


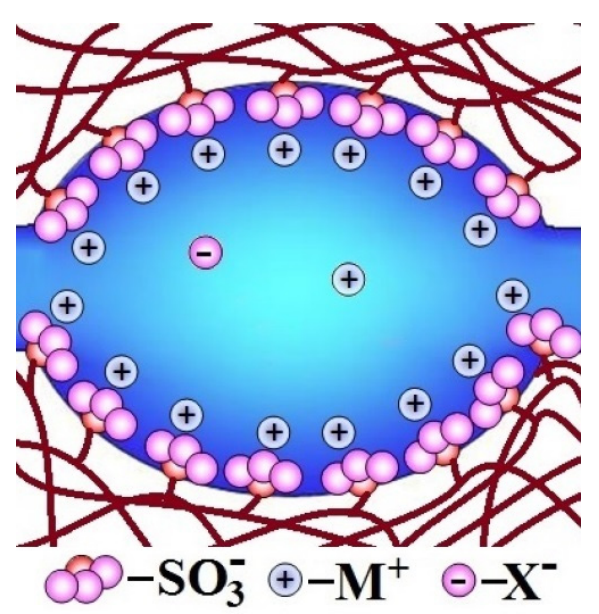

(a)

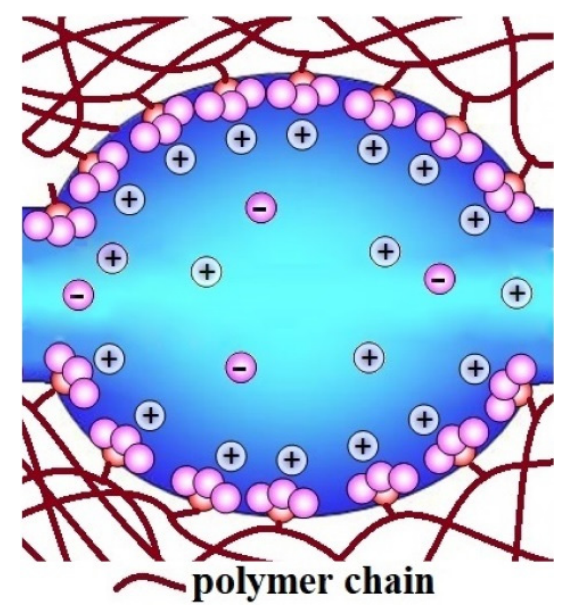

(b)

Figure 2. Illustration of the change in pore-channel system of membranes with increasing water uptake (from (a) to (b)).

The reasons for this relationship between water uptake, conductivity, and selectivity of ion-exchange membranes can be seen in Figure 2. With increasing membrane water uptake, the size of pores and channels also increases (Figure 2a). In its turn, an increase in the size of the channels results in an increase in the ion mobility and the ionic conductivity of membranes. On the other hand, there is a significant increase in the coion concentration, which is determined by the fraction of the electroneutral solution in the membrane (Figure $2 b$ ). This is the main reason for the increase in the flow of coions and a decrease in the selectivity of ion-exchange membranes with high water uptake. These regularities are typical for both cation-exchange and anion-exchange membranes [91-94].

It is worth mentioning that the membrane pretreatment at elevated temperatures, pressures as well as the change of the solvent nature (for example, to water-alcohol) also leads to some changes in pore volume, conductivity, and selectivity. These effects were discussed in recent reviews [60,95].

Ion transfer in ion-exchange membranes occurs in solution localized inside the pores, and its mechanism is similar to the mechanism of ion transfer in solutions. For most cations, it includes hopping between different positions, accompanied by the destruction and the reformation of hydration shells. For membranes with low water uptake, some positions in their environment can be occupied by fixed ions (- $\mathrm{SO}_{3}{ }^{-}$groups) [96]. For membranes in the hydrogen form, the transfer mechanism changes somewhat and includes a sequence of proton-containing group rotations and proton hops along hydrogen bonds. Moreover, at a high water uptake, cooperative effects play a significant role and proton transfer by the Grotthuss mechanism dominates [97].

The discussed above model for perfluorinated sulfonic acid membrane morphology, is often used for heterogeneous membranes. However, they are usually obtained by hot rolling or pressing of an ion-exchange resin and a plastic binder. Due to this, large macropores remain between their granules [32,36,98-100]. Such pores appear between the ion exchanger granules and the plasticizer during the membrane formation as the package defects. As a result, the pore size distribution in heterogeneous membranes is bimodal. The main part of the pores in size (several $\mathrm{nm}$ ) and structure is close to those for homogeneous membranes, while the other part of the pores is larger (about $1 \mu \mathrm{m})[35,101]$. The transfer through these macropores cannot be selective. Therefore, the heterogeneous membrane selectivity is usually lower than that of homogeneous ones [36,102,103]. Reinforcing mesh used to increase the mechanical strength of heterogeneous membranes can also contribute to a decrease in selectivity [104]. 


\section{Pseudo-Homogeneous and Grafted Membranes}

The obvious desire is to create relatively cheap membranes, for example, similar in composition to heterogeneous ones, but with high selectivity like in homogeneous membranes, primarily perfluorinated sulfonic acid membranes. To do this, one should get rid of the macropores formed during the heterogeneous membrane preparation. The most evident approach seems to prepare homogeneous membranes based on sulfonated polystyrene (PS), which is the basic ion-exchange material for the preparation of most of heterogeneous membranes. However, it is impossible to obtain films with good mechanical properties from it. That is why a binder, most often polyethylene, is used to form heterogeneous ion-exchange membranes $[32,105,106]$.

From this point of view, it seems logical to use alternative methods for the preparation of IEMs of a similar composition by chemical synthesis. In particular, such a "defect-free" combination of functionalized PS and hydrophobic polymer can be achieved in the block copolymer synthesis, e.g., IEMs based on triblock styrene-ethylene/butylene-styrene copolymers $[107,108]$. The well-known Neosepta ${ }^{\circledR}$ membranes are prepared by polymerization of styrene in a paste with polyvinyl chloride particles $[109,110]$.

Another promising approach is the grafted copolymer synthesis based on the radical polymerization of styrene directly inside the hydrophobic film [111-114]. For example, irradiation of polyethylene with $\gamma$-rays results in its radical formation. Usually, the lifetime of the radicals is very short and due to their high reactivity, they annihilate very quickly, but in the polymer film they can exist for a long time, at least for several months. The reason for this is the low mobility of polymer chains, which prevents annihilation. This allows one to separate the stages of irradiation and polymerization. By varying the radiation dose and the time of styrene polymerization, it is possible to obtain a material based on the irradiated polyethylene films with different polystyrene content [115-117]. In this case, polystyrene is formed as a separate phase in a dense polyethylene film, as if expanding the polyethylene chains without pore formation. Thus, through subsequent sulfonation, ion-exchange membranes with a wide range of ion-exchange capacities and fairly uniform distribution of $-\mathrm{SO}_{3}{ }^{-}$groups over the membrane thickness were prepared $[115,118,119]$. However, membranes with a high degree of grafting and sulfonation swell too much in water, losing their mechanical strength and selectivity. To prevent this, crosslinking with divinylbenzene can be used. Such polymers have a heterogeneous structure, but due to the fact that the heterogeneity size is less than the visible light wavelength, IEMs based on them are transparent. Therefore, they are usually called pseudo-homogeneous. A similar approach was used for a number of polymers [120-124] and allowed authors to obtain materials with desired properties for a number of electromembrane processes [112,125,126].

Radical creation by softer activation, e.g., using ultraviolet radiation is more attractive. However, its energy is not enough to activate polyethylene. For this reason, a polymer containing tertiary carbon atoms, e.g., polymethylpentene, is needed. Its activation allows for the polystyrene grafting with subsequent sulfonation and crosslinking. As a result, a number of cation-exchange membranes (CEMs) with a wide range of ion exchange capacities were prepared [84] as well as anion-exchange membranes (AEMs), which surpass the best commercial membranes in their properties [127].

Styrene polymerization inside stretched films of polyethylene or other polymers can be considered as an alternative approach. Mechanical deformation resulted in formation of multiple small pores inside them, which are then filled with polystyrene [119,128-130]. This approach does not prevent the preservation of sufficiently large pores inside the polymer, but in some cases, it is possible to obtain membranes with high selectivity, which can be judged, for example, by their high efficiency in fuel cells.

Depending on the application, membrane materials with high ionic conductivity or selectivity are necessary, but in any case, both of these parameters are important. In particular, for electrodialysis, the ratio of conductivity to cation transfer numbers is most important. The relationship between them can be found from a consideration of the transport of counterions and coions through membranes on the basis of the irreversible thermodynamics [131]. The authors concluded that cation transfer 
numbers should increase with ionic conductivity increasing. However, due to the reasons discussed in the previous section, their ratio usually turns out to be the reverse.

To compare membrane conductivity and selectivity, a two-dimensional diagram can be used (Figure 3). Membranes with the best transport properties are near the so-called "upper bound". Homogeneous perfluorosulfonic acid membranes have the best properties among the commercial membranes. They are followed by pseudo-homogeneous and heterogeneous ones. At the same time, the best of the samples of grafted membranes based on polymethylpentene and sulfonated polystyrene match the best perfluorosulfonic acid membranes.

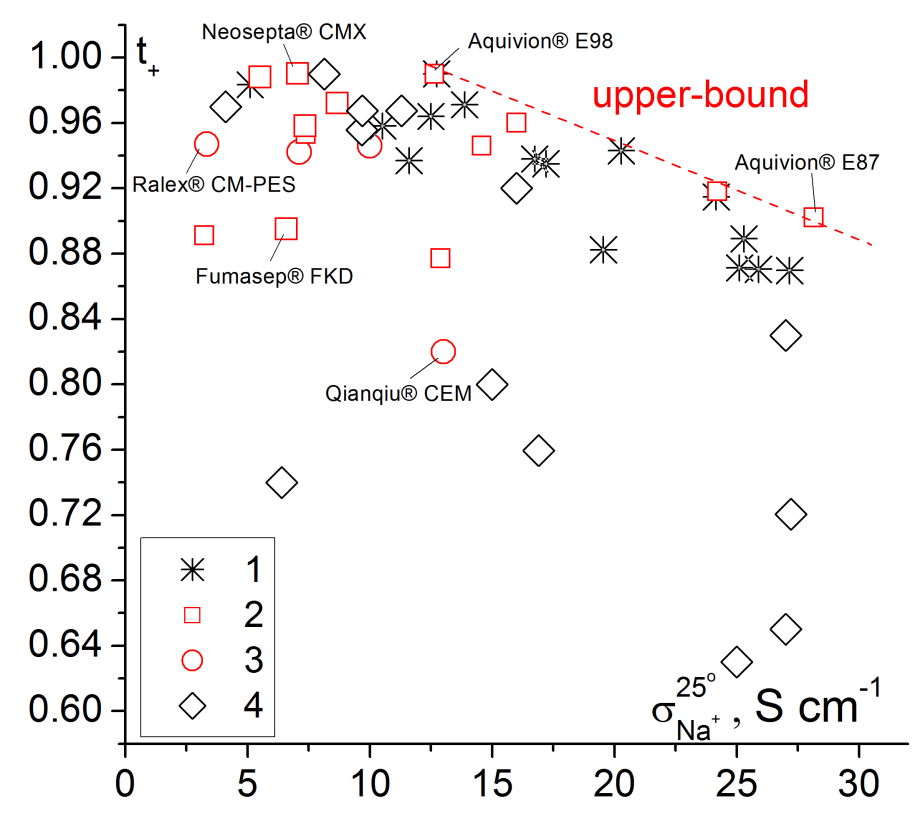

Figure 3. Dependence of apparent transport numbers $(0.5 / 0.1 \mathrm{M} \mathrm{NaCl})$ on the $\mathrm{Na}^{+}$conductivity of various cation exchange membranes. 1-grafted membranes based on UV-oxidized polymethylpentene [84], 2-homogeneous and pseudo-homogeneous materials, 3-heterogeneous membranes, 4-grafted membranes based on polyethylene [115,132]. Some trade names of commercially available membranes are shown in the Figure.

It should be noted that many commercially available ion-exchange membranes used in electromembrane processes, for example, Neosepta ${ }^{\circledR}$, Fumatech ${ }^{\circledR}$, FujiFilm ${ }^{\circledR}$ membranes and others have the pseudo-homogeneous morphology. When designing pseudo-homogeneous IEMs, it is possible to adjust their properties by changing the nature and proportion of the hydrophobic polymer matrix, the degree of functionalization, the nature of the functional group, using reinforcement or crosslinking.

Let us consider how the above factors affect the water uptake of ion-exchange membranes and, hence, their selectivity. Typically, an increase in the proportion of the hydrophobic polymer matrix and its rigidness leads to a decrease in water uptake $[84,109,115,133-136]$. For example, Gupta et al. showed that an increase in the grafting degree of sulfonated polystyrene for the radiation grafted FEP-g-polystyrenesulfonic acid membranes from 6 to $40 \%$ leads to an increase in water uptake from 2-3 to 63 water molecules per sulfonic-acid group [137]. The authors of [138] demonstrated that an increase in the crystallinity of the cation exchange membranes from 8 to $25 \%$ leads to a decrease in their water uptake from 32 to 19 water molecules. It should be noted that the CMX Neosepta ${ }^{\circledR}$ membrane, which made of high rigid polyvinyl chloride, is one of the most mechanically tough and selective commercial IEMs. This is due to the fact that the limitation of the swelling of the hydrophilic ionic domains is accompanied by an increase in their selectivity. Another important parameter is the amount of functional groups $[82,136,139,140]$. For example, an increase in the sulfonation degree of polystyrene in the cation-exchange membranes based on block copolymers from 12 to $49 \%$ leads to an increase in water uptake from 3 to 165 water molecules per sulfonic-acid group. 
For anion-exchange membranes, the nature of the functional group represented by various quaternary amines is especially relevant [82,141]. Therefore, Cho et al. [82] showed that AEM based on substituted imidazoles have higher selectivity than those with the trimethylamine functional groups, which was associated with their lower hydration degree. A similar correlation is well known for cation-exchange membranes: during electrodialysis of $\mathrm{NaCl}$ solution, Nafion-type membranes with a carboxyl functional group [142,143] are more selective in comparison with more hydrophilic sulfonic acid-based membranes. Another example of ionogenic group nature on swelling properties is CEM with sulfonylimide ionogenic groups showing a high swelling and ionic conductivity in water/organic amide mixed systems [144] compared with sulfonic acid-based membranes.

Ion exchange membranes are often reinforced to improve their selectivity, mechanical properties, or to prevent significant dimensional changes during hydration or drying [145-149]. Polymeric meshes, nonwoven materials, and organic and inorganic fibers are generally used for membrane reinforcement. The reinforcing material often forms directly during the synthesis. Thus, if the membranes are prepared via the polymerization between hot squeezing rollers or plates, the reinforcing mesh controls the thickness of the final film and does not allow the reaction mixture to leak out under pressure $[150,151]$. In some cases, the monomer polymerization takes place directly in the reinforcing material matrix $[119,128,152]$. By limiting the swelling of the conductive ionic phase, suitable membrane selectivity can be maintained. However, it is worth noting that high membrane selectivity can only be achieved if reliable adhesion is ensured between the reinforcing and ionic materials and there are no macropores between them. Otherwise, reinforcement will lead to macropore formation and a decrease in selectivity [104].

\section{Cross-Linking of Polymer Membranes}

It can be assumed that there is a certain optimal size of pores and channels connecting them to ensure a good combination of ionic conductivity and selectivity of ion-exchange membranes. On the one hand, to provide high ionic conductivity of the membranes, large channels and pores are required, and hence a high water uptake. However, if we refer to the example with grafted membranes, the fact that membranes with intermediate water uptake have optimal transport properties can be seen [84]. At low water uptake, the whole pore/pore volume is covered by a double electric layer and the coion concentration in them is negligible. Therefore, the selectivity should be very high. But narrow channels and weak pore connection determine too low conductivity of such materials. Even at a high water uptake of the ion-exchange membranes equilibrated with water, the counterion concentration in the inter-pore solution is quite high (about $2-3 \mathrm{~mol} / \mathrm{L}$ ). Therefore, as a first approximation, the Debye layer thickness is assumed to be constant. With increasing water uptake, the pore size increases mainly due to an increase in the volume of the electrically neutral solution. Thus, with water uptake increasing, the counterion transport numbers, corresponding to the membrane selectivity, should decrease.

Another factor determining the conductivity is the charge carrier concentration [97], which is determined by the counterion concentration. Since in most applications, membranes with functional groups based on strong acids and bases are used, it can be assumed that in the hydrated state the dissociation degree of functional groups is close to one and the carrier concentration is determined by the ion-exchange capacity. However, an increase in the concentration of functional groups in the hydrophobic polymer matrix unambiguously leads to an increase in water uptake and, hence, to an increase in the carrier mobility. Since water in the membrane matrix acts as a plasticizer, the elasticity of the matrix, which determines its swelling degree, increases with water uptake increasing. Moreover, a lot of ion-exchange materials with a high ion-exchange capacity lose their mechanical properties or even become water-soluble. This limits their practical application.

In fact, this means that strategies aiming at increasing the membrane conductivity by increasing its ion-exchange capacity or water uptake should definitely decrease its selectivity and the mechanical properties [107,153-155]. One of the solutions is the cross-linking of polymer chains. This limits the 
membrane swelling degree and, hence, leads to an improvement in their selectivity and mechanical properties [156-159].

In a number of synthetic approaches, cross-linked agents, e.g., divinylbenzene (DVB), can be added to the ionomer during polymerization. Using such methods, highly selective membranes are often obtained. For example, the Neosepta ${ }^{\circledR}$ CMX membrane based on a sulfonated styrene-divinylbenzene copolymer (s-PS-DVB) has apparent cation transport number of $99 \%$ $(0.5 \mathrm{M} / 0.1 \mathrm{M} \mathrm{NaCl})$, low permeability for sodium chloride and contains 7-9 water molecules per functional group in the $\mathrm{Na}^{+}$-form [160]. Kang et al. [128] showed that an increase in the cross-linking degree for grafted membranes based on sulfonated polystyrene can halve the membrane hydration degree as well as reduce its methanol permeability by 1.8 times. Generally, ion-exchange membrane manufacturing methods, including solvent casting stage, do not imply the possibility of medium or highly cross-linked materials preparation. Cross-linking method requires additional processing steps or the introduction of special groups (reactive sites) [3,161-163]. Such approaches are rather relevant for membranes based on polyetheretherketones, polysulfones or block copolymers based on polystyrene and polyolefins. It is worth noting that this can significantly increase the membrane cost.

Most often, divinylbenzene is used as cross-linker in ion-exchange membranes based on styrene copolymers. As shown in $[132,164,165]$, the use of more flexible cross-linkers, for example, bis (vinylphenyl) ethane (Figure 4), allows manufacturing ion-exchange membranes with a better selectivity/conductivity ratio. In particular, at close transfer numbers, the ionic conductivity of membranes crosslinked with bis (vinylphenyl) ethane is four times higher than that of membranes cross-linked by divinylbenzene [132]. This effect is explained by the close reactivity of bis (vinylphenyl) ethane and styrene, which provides more uniform cross-linking and more optimal membrane structure.

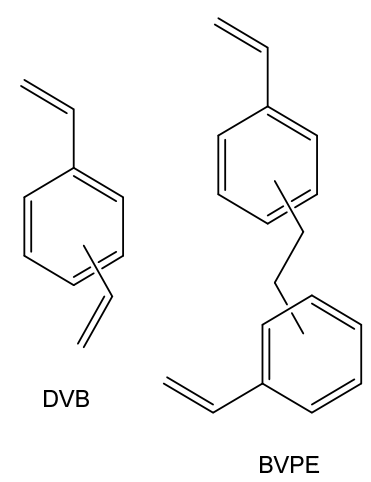

Figure 4. Chemical structures of crosslinking agents: divinylbenzene and bis (vinylphenyl) ethane.

At this point, it is also worth considering IEMs based on strongly cross-linked matrices obtained by polymerization of aqueous or amide solutions of ionogenic monomers, such as functionalized acrylamides or styrenes [151,166-168]. Well known Fujifilm ion-exchange membranes also belong to this class of materials $[104,169]$. Due to the high cross-linker content, reaching $60 \%$, a three-dimensional network is formed during the polymerization, which does not swell like ordinary membranes. Therefore, the maximum water uptake of such membranes is limited by the initial solvent volume, which determines the free volume (Figure 5). However, the hydration degree of such membranes is usually more than 18-20 water molecules per one functional group, due to the limited solubility of the monomers and cross-linkers in the reaction mixture. Of course, this to some extent limits the selectivity of such materials. Note that this approach leads to a paradoxical for other types of ion-exchange membranes effect-an increase in the functional group concentration in these membranes leads to a decrease in water uptake per functional group and an increase in selectivity $[168,170,171]$. 


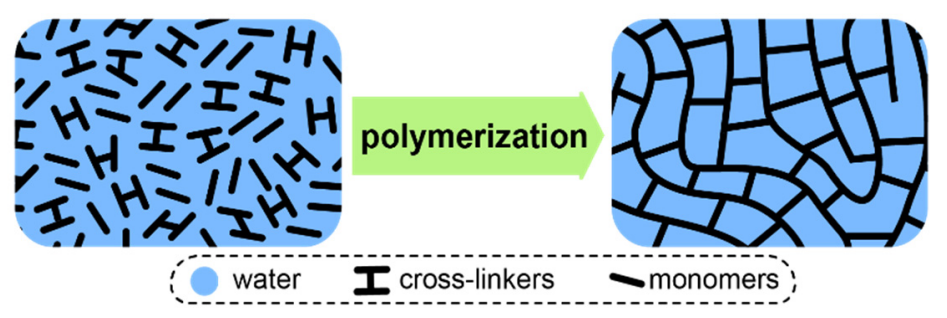

Figure 5. Formation of a typical highly cross-linked membrane via polymerization of aqueous or amide solutions of ionogenic monomers.

\section{Hybrid Membranes}

Another approach to increase the selectivity and decrease the water uptake of ion-exchange membranes is to replace part of the water in the pores by the inorganic particle's incorporation. Since the membrane pore size is usually small and does not exceed $5 \mathrm{~nm}[62,172]$, the size of the introduced particles should also be several nanometers. Doping with inorganic nanoparticles has been used to improve the transport properties of membrane materials since the late 1980s [173-177]. Since organic and inorganic components are simultaneously present in such systems, such membranes are called hybrid membranes. Research in this area was almost simultaneously developed for gas separation membranes, which are often called the Mixed Matrix Membranes [178,179].

In the case of ion-exchange membranes, this approach is more often used to increase their ionic conductivity. For this purpose, nanoparticles of hydrophilic materials, such as silica [180-187], or other oxides [188-199] are used. This often leads to an increase in the membrane water uptake, and therefore it is often believed to be the reason for the conductivity increase. However, in a number of hybrid membranes, the conductivity increases despite the lower water uptake. To explain this effect, a model of limited elasticity of the membrane pore walls was proposed [200]. Upon doping, inorganic nanoparticles should displace a part of water molecules from the pore. Since the counterion concentration remains almost the same, this leads to an increase in the osmotic pressure and a pore expansion (Figure 6a,b), accompanied by an expansion of the channels connecting them and, hence, a conductivity increase. However, with increasing nanoparticle size, the elastic forces of the pore walls increase according to Hooke's law and the osmotic pressure becomes insufficient for their further expansion. Therefore, the membrane water uptake decreases, and new "bottlenecks" that limit conductivity appear in the pores (Figure 6c). When the additive content is above two vol \%, the conductivity of the hybrid membranes decreases [180,201-203]. This model is confirmed by comparing the data on the ionic conductivity of hybrid membranes with the diffusion coefficients of proton-containing groups determined by NMR with a pulsed magnetic field gradient $[201,204]$. The authors of [205] developed this model and described with its help the effect of a double electric layer formed around nanoparticles embedded in mesopores and macropores on the electrical conductivity, diffusion permeability of IEMs, and ion transport numbers in them.

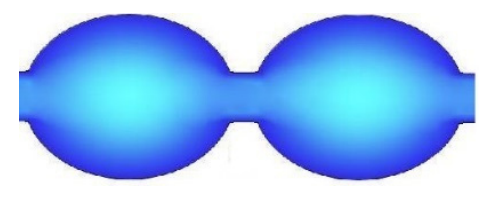

(a)

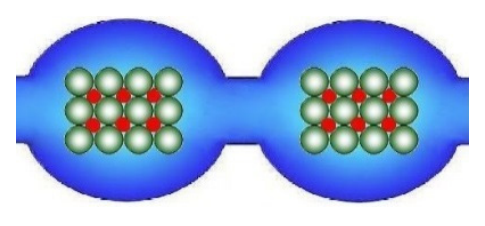

(b)

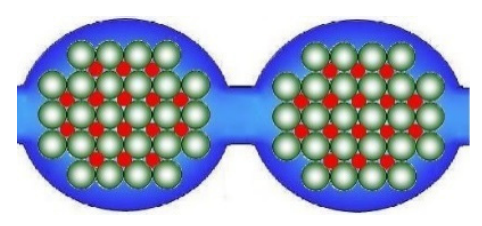

(c)

Figure 6. Scheme of the pore structure change: the initial membrane (a) and membranes modified with nanoparticles of different sizes $(\mathbf{b}, \mathbf{c})$ according to the case of the model of limited elasticity of the pore walls (redrawn from [206]). 
Increased conductivity is not the only advantage of hybrid membranes. Some authors also note an improvement in their mechanical properties $[177,207,208]$. Although it is not always achieved, the mechanical properties of hybrid membranes are usually sufficient for their practical use $[16,209]$.

A noteworthy advantage of hybrid membranes is often their reduced permeability of methanol and other fuel gases [202,210-212]. This determines, in particular, the widespread use of hybrid membranes in direct methanol fuel cells (DMFCs) [16,213,214]. A comparison of proton conductivity and methanol permeability for a number of hybrid membranes is given in Table 1.

Table 1. Comparison of the proton conductivity and methanol permeability of various PEMs for DMFCs application.

\begin{tabular}{|c|c|c|c|}
\hline Material & $\begin{array}{l}\text { Proton Conductivity } \\
(\mathrm{S} / \mathrm{cm})\end{array}$ & $\begin{array}{l}\text { Methanol Permeability } \\
\qquad\left(10^{-7} \mathrm{~cm}^{2} / \mathrm{s}\right)\end{array}$ & Reference \\
\hline $\begin{array}{c}\text { SPAEEKK } \\
\text { SPAEEKK/sulfonated silica }\end{array}$ & $\begin{array}{c}0.012 \\
0.043 \\
\left(20^{\circ} \mathrm{C}, 100 \mathrm{RH}^{1}\right)\end{array}$ & $\begin{array}{l}7.83 \\
4.86\end{array}$ & [215] \\
\hline $\begin{array}{c}\text { Recast Nafion } \\
\text { Recast Nafion/silica }\end{array}$ & $\begin{array}{c}0.043 \\
0.034 \\
\left(20^{\circ} \mathrm{C}, 100 \mathrm{RH}\right)\end{array}$ & $\begin{array}{l}7.53 \\
4.17\end{array}$ & [180] \\
\hline $\begin{array}{c}\text { Nafion-117 } \\
\text { Sulfonated polyimide } \\
\text { Sulfonated polyimide/GO }\end{array}$ & $\begin{array}{c}0.038 \\
0.0021 \\
0.0025 \\
\left(60^{\circ} \mathrm{C}, 60 \mathrm{RH}\right)\end{array}$ & $\begin{array}{l}85.9 \\
20.7 \\
4.31\end{array}$ & [216] \\
\hline $\begin{array}{c}\text { Nafion-212 } \\
\text { Nafion/ } \mathrm{SiO}_{2} / \mathrm{m}-\mathrm{BOT} \text { (bentonite } \\
\text { modified by dodecylamine) }\end{array}$ & $\begin{array}{c}0.0991 \\
0.0667 \\
\left(35^{\circ} \mathrm{C}, 60 \mathrm{RH}\right)\end{array}$ & $\begin{array}{l}1.34 \\
0.25\end{array}$ & [184] \\
\hline $\begin{array}{c}\text { Recast Nafion } \\
\text { Recast Nafion/aminoacid functionalized } \\
\mathrm{SiO}_{2} \text { nanofiber }\end{array}$ & $\begin{array}{c}0.075 \\
0.1404 \\
\left(20^{\circ} \mathrm{C}, 100 \mathrm{RH}\right)\end{array}$ & $\begin{array}{c}14 \\
10.2\end{array}$ & [187] \\
\hline $\begin{array}{c}\text { SPEEK } \\
\text { SPEEK/Aminofunctionalized titania sol }\end{array}$ & $\begin{array}{c}0.0179 \\
0.0624 \\
\left(20^{\circ} \mathrm{C}, 100 \mathrm{RH}\right)\end{array}$ & $\begin{array}{l}6.51 \\
5.82\end{array}$ & [217] \\
\hline $\begin{array}{c}\text { Pristine recast Nafion } \\
\text { Nafion-silica nanopowder }(5 \mathrm{wt} \%) \\
\text { Nafion-silica MSU-F silica } \\
\text { meso-structured cellular foam }(0.5 \mathrm{wt} \%) \\
\text { Nafion-silica MCM-41 }(0.25 \mathrm{wt} \%)\end{array}$ & $\begin{array}{c}0.051 \\
0.084 \\
0.137 \\
0.100 \\
\left(30^{\circ} \mathrm{C}, 100 \mathrm{RH}\right)\end{array}$ & $\begin{array}{l}6.4 \pm 0.1 \\
4.8 \pm 0.1 \\
1.4 \pm 0.1 \\
2.5 \pm 0.1\end{array}$ & [183] \\
\hline
\end{tabular}

${ }^{1}$ RH-relative humidity.

It is worthwhile to note that gas permeability can be considered as a measure of selectivity of membranes used in fuel cells and the transfer mechanism of non-polar gas molecules or alcohols containing voluminous non-polar fragments is much similar to that of coions. They are also displaced by polar water molecules and cations from the double electric layer and are localized mainly in the electroneutral solution.

The increase in selectivity of hybrid membranes can be explained by the model of limited elasticity of their pore walls (Figure 6). When additive particles are introduced, they displace a part of the electroneutral solution localized in the pore center, thereby decreasing the solubility of gases or alcohols as well as crossover in fuel cells. However, considering the conductivity and selectivity of hybrid membranes, it is necessary to take into account the nature of additive particles or their surface. It has already been noted above that the particle surface should, whenever possible, be hydrophilic for conductivity enhancement. The acid properties of its surface are no less important.

If the additive surface contains strong acid groups, as result of their dissociation, an additional number of counterions (protons, charge carriers) are formed. In this case, the nanoparticle surface acquires a charge of the same sign as the pore walls of cation-exchange membranes. These filler particles should repel from them due to the electrostatic effects, be located in the pore center, and displace only the electrically neutral solution. Moreover, their surface charged negatively will create an additional 
double electric layer, contributing to the displacement of coions and non-polar molecules as a result of competition with polar water molecules, which interact much more strongly with the charged pore walls. Moreover, such nanoparticles should not decrease the counterion transport along the pore walls, on the contrary, they will contribute to its increase due to an increase in the charge carrier concentration $[67,205]$. Heteropoly acids, their acid salts with alkali metal cations, or silica particles with heteropoly acids were shown to improve conductivity in such way [218-225]. On the other hand, the surface of such particles is hydrophilic, which contributes to an increase in water uptake. When the composite membranes Nafion/ $/ \mathrm{SiO}_{2} / \mathrm{PWA}$ and Nafion/ $/ \mathrm{SiO}_{2}$ were employed as an electrolyte in $\mathrm{H}_{2} / \mathrm{O}_{2}$ PEMFC, the higher current densities ( 540 and $320 \mathrm{~mA} / \mathrm{cm}^{2}$ at $0.4 \mathrm{~V}$, respectively) were obtained than that of the Nafion- 115 membrane $\left(95 \mathrm{~mA} / \mathrm{cm}^{2}\right)$, under the operating condition of $110^{\circ} \mathrm{C}$ and at the humidified temperature of $100^{\circ} \mathrm{C}$ [219].

The opposite situation can be realized if the membrane is doped by nanoparticles with the basic surface [226,227]. In this case, "salt bridges" are formed between the functional groups of the membrane and the basic surface groups, e.g., of the $-\mathrm{SO}_{3}-\mathrm{HNR}_{3}$ type. Their formation decreases the ion-exchange capacity of the membrane and constricts the pore walls, decreasing pore size and water uptake. Despite the fact that the additive surface in this case is also hydrophilic, actually, its basic functional groups interact with the acid groups of the pore walls, reducing their solvation and turns out to be an additional factor that reduces the water uptake and leads to an increase in selectivity of these membranes [228]. In fact, in this case, the role of doping turns out to be similar to that of cross-linking - the membrane conductivity decreases while selectivity increases.

The influence of the dopant surface acidity on the properties of cation-exchange membranes based on polymethylpentene with grafted sulfonated polystyrene has been studied in [229]. $\mathrm{ZrO}_{2}, \mathrm{TiO}_{2}$, and $\mathrm{SiO}_{2}$ with increased acidic properties were used as dopants. Their $\mathrm{pK}_{\mathrm{a}}$ values vary somewhat depending on the preparation method and are 11-12, 8-9, and 5-6, respectively [230]. If the first of them mainly exhibits basic properties, those of the last one are acidic. The ion-exchange capacity and conductivity of hybrid membranes naturally increase in this series of dopants (Table 2). If in the case of zirconia and titania the ion exchange capacity decreases due to the formation of salt bridges (hydrogen ionic bonds of the type $-\mathrm{M}-\mathrm{O}_{3} \mathrm{~S}-$ ), silica does not change it. Based on Poisson-Boltzmann equations, the fraction of negatively charged groups on the surface of a silica nanoparticle at $\mathrm{pH}=6$ estimated to be in the range of $5-10 \%$ [231]. This result is in good agreement with the electrokinetic experimental data reported by Sonnefeld et al. [232]. Dissociation of OH-groups of silica showing weak acid properties is suppressed in the presence of a strong sulfonic acid (sulfonated polystyrene). At the same time, the ionic conductivity of this membrane significantly increases as result of increased pore size and water uptake.

Table 2. Ionic conductivities and apparent transport numbers of some grafted hybrid CEM in $\mathrm{Na}^{+}$ form with the dopant content of $8-10 \mathrm{wt} \%$ [229].

\begin{tabular}{ccccc}
\hline Property & Initial Membrane & $\mathbf{Z r O}_{\mathbf{2}}$ & $\begin{array}{c}\text { Dopant } \\
\mathbf{T i O}_{\mathbf{2}}\end{array}$ & $\mathbf{S i O}_{\mathbf{2}}$ \\
\hline $\mathrm{IEC} \mathrm{mg} \mathrm{eq} / \mathrm{g}$ & 2.1 & 1.1 & 1.9 & 2.1 \\
$\omega\left(\mathrm{H}_{2} \mathrm{O}\right), \mathrm{wt} \%$ & 50 & 29 & 45 & 55 \\
$\sigma_{\mathrm{Na}+}, \mathrm{mS} \mathrm{cm}^{-1}$ & 25.3 & 10.1 & 22.3 & 31.6 \\
$(\mathrm{in} 0.5 \mathrm{M} \mathrm{NaCl})$ & 88 & 95 & 88 & 81 \\
$\mathrm{t}_{+ \text {app }}{ }^{1}$ & 88 &
\end{tabular}

${ }^{1}$ apparent transport number measured between $0.5 \mathrm{M}$ and $0.1 \mathrm{M} \mathrm{NaCl}$ solutions.

At the same time, the selectivity of ion-exchange membranes significantly decreases in the $\mathrm{ZrO}_{2}-\mathrm{TiO}_{2}-\mathrm{SiO}_{2}$ series. When zirconia is used as a dopant, the apparent cation transport numbers increase by $7 \%$ compared with the initial membrane, for silica it decreases by the same $7 \%$. After the $\mathrm{ZrO}_{2}$ introduction, the proton conductivity sharply decreases due to the formation of salt bridges. At the same time, after membrane treatment with $1 \mathrm{M}$ alkali solution, its conductivity increases and 
reaches almost the same values as for the initial membrane. This change is due to the destruction of salt bridges in the alkaline medium. It should be noted that this effect is reversible-during cyclic treatment with acid and alkali solutions, the conductivity almost reversibly returns to the values of the hydrogen and sodium forms of hybrid membranes, respectively [229].

An increase in the selectivity of transport processes was also noted upon membrane doping with such a weak base as polyaniline [233-236]. Recently, much attention has been paid to carbon nanomaterials, primarily carbon nanotubes (CNT). They have gained attention due to unique structure and properties such as extraordinary mechanical properties, high surface area, electronic conductivity and chemical stability. Carbon nanotubes are mostly used in fuel cells as a catalytic support for the oxygen reduction reaction [237]. However, carbon nanomaterials have also been used as fillers for fuel cell membranes, e.g., the CNTs introduction can improve their mechanical properties $[237,238]$. Some authors also reported a decrease in the membrane permeability to methanol as well as its crossover in direct methanol fuel cells with CNTs introduction [237]. The use of carbon nanotubes with a sulfonated surface for this purpose is especially effective, since they can increase the proton conductivity of membranes due to additional charge carrier introduction [239-242]. Moreover, the negatively charged surface of sulfonated CNTs creates an additional double electric layer around them and increases the membrane selectivity. This leads to a decrease in the methanol permeability of such hybrid membranes and an increase in the fuel cell power $[239,243]$. For example, a decrease in the methanol permeability of the obtained hybrid membrane by more than 3 times was shown [244]. At the same time, the authors of [245] noted that at very high sulfonation levels a morphological transition caused a decrease in transport properties. There is information about increase in the conductivity of sulfonated poly (etheretherketone) membranes due to their doping with CNTs coated with silica [246] as well as CNTs with imidazole groups on their surface $[247,248]$.

Other carbon materials as dopants for proton-conducting membranes are less studied. However, in recent years, composite materials with graphene have received much more attention [249]. Among the advantages of composite Nafion/graphene membranes, increased proton conductivity is noted [250]. At the same time, the authors of [251] reported a decrease in conductivity and methanol permeability of such membranes. The proton conductivity of sulfonated graphene-Nafion composite membranes at low humidity (20-25\% RH) was found to be five times higher than that of a pristine Nafion membrane, while a peak power density of fuel cells based on them is 1.5 times higher $[252,253]$.

\section{Membranes with Modified Surface}

The surface of ion-exchange membranes largely determines their transport properties. Therefore, its modification has long been considered as one of the ways to improve the properties of ion-exchange membranes [32,254]. Various approaches were used for this. The membrane surface profiling is one of the simplest ways. This approach is more effective for modification of heterogeneous membranes [255-260]. Most of their surface $(75-85 \%[98,261])$ is covered with a plasticizer (polyethylene) film, which is formed during pressing. Only $15-25 \%$ of the surface is occupied by ion-exchange resin particles which protrude over the polyethylene film and provide ion transport (Figure 7).

Profiling results in an increase in the active surface area both due to the increase the surface area itself and by reducing the polyethylene coating area. The presence of a profile on the membrane surface significantly reduces both the diffusion path length and the effective thickness of the diffusion layer due to the optimization of hydrodynamic conditions [257-259,262-264]. The appearance of the tangential component of the electric force acting on the space charge of the solution at the surface of the protrusions results in an increase in electroconvection. During electrodialysis of dilute solutions, this effect leads to an increase in the mass transfer rate through profiled membranes up to 8 times [265]. 


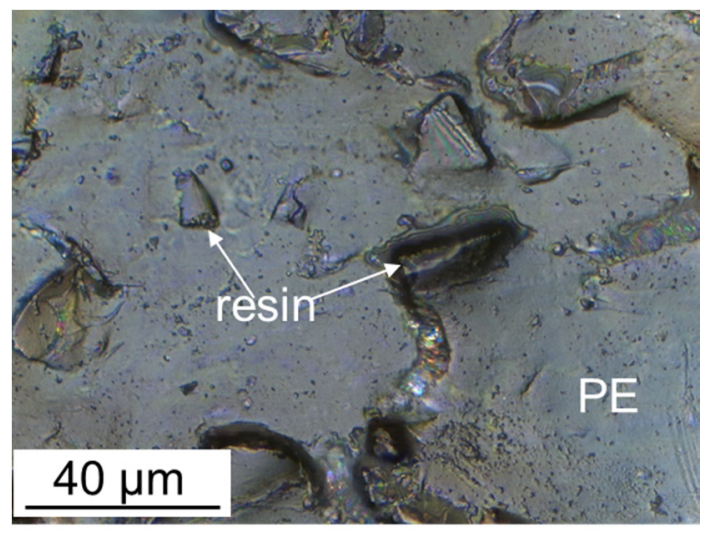

Figure 7. Optical image of the surface of the swollen MA-41 heterogeneous membrane; " $\mathrm{PE}^{\prime \prime}$ is the polyethylene binder, "resin" is the ion-exchange resin particle protruding over the polyethylene film (redrawn from [36]).

In a number of studies, plasma treatment was used to modify the surface layer of membranes. In some cases, this leads to an increase in pore size in the surface layer and to a decrease in selectivity [266]. Choi et al., on the contrary, reported that plasma treatment reduces the methanol crossover in Nafion membranes with a simultaneous decrease in proton conductivity as a consequence of the removal of a part of the functional groups [267]. Lee et al. explained a decrease in the methanol crossover of the membranes modified by ion implantation by both the removal of sulfonic acid groups and their substitution by $\mathrm{COOH}, \mathrm{OO}, \mathrm{CO}$-groups [268]. The coating of a thin fluorocarbon layer on the surface of perforated membranes allowed reducing the wettability of their surface and the methanol permeability by two orders of magnitude [269]. Plasma carbon deposition on the membrane surface led to similar results [270]. It is also reported that, using plasma treatment, aluminosilicate nanotubes can be introduced into the surface layers of membranes [271].

As mentioned above, the properties of heterogeneous membranes are largely determined by the imperfection of their surface, which is usually predominantly coated with a plasticizer, e.g., polyethylene. From this point of view, coating it with a thin layer of polyelectrolyte with better conductivity seems reasonable [272,273]. Perhaps, homogeneous perfluorosulfonic acids of the Nafion ${ }^{\circledR}$ type are one of the optimal materials for coating heterogeneous cation-exchange membranes. Such a coating does not increase the cost of heterogeneous membranes too much, but gets their properties similar to those of homogeneous ones, increasing their conductivity and improving the performance of electromembrane processes at super-limiting currents [274,275]. A perfluorosulfonated polymer film on the surface of a heterogeneous membrane can significantly reduce or even eliminate deposition of sparingly soluble salts on the membrane surface during electrodialysis $[276,277]$. Of considerable interest is the chemical modification of the AEM surface with a bifunctional polymer solution allowing transforming the functional tertiary and secondary amino groups into the quaternary ones [36,278]. Such a modification can significantly reduce the intensity of undesirable generation of $\mathrm{H}^{+}$and $\mathrm{OH}^{-}$ions near the AEM surface [36] due to a decrease in the concentration of secondary and tertiary amino groups in the membrane surface layer, which exhibit high catalytic activity in this process [279]. An additional improvement in the properties of such membranes can be achieved by modifying the surface coating with inorganic oxide nanoparticles [280]. It can also be noted that membranes with a deposited surface layer can regulate the transfer rates of ions with different charge sizes [56], since multicharged ions predominantly adsorbed in the membrane pores limit the transfer of monovalent ones [281,282].

Bipolar membranes containing two layers (cation-and anion-exchange) with functional groups of the opposite charge are one of the important types of ion-exchange membranes. Due to their high selectivity, they have been successfully used in a number of applications. Very interesting is the recently discovered possibility to convert sunlight into ionic electricity with bipolar membranes [283] and to apply this energy for $\mathrm{CO}_{2}$ reduction [284] and for water electrolysis [285-292]. The use of bipolar 
membranes is also advantageous in reverse electrodialysis [293] and in storage of electrical energy using flow batteries [294]. There is another effective way to improve the selectivity of membranes by coating layers with fixed groups of opposite charge. For example, the surface of cation exchange membranes can be modified with polyethyleneimine [295-299] or polyaniline [234,300-303]. It should be noted that such membranes also differ in the asymmetry of ion transport and, in particular, in diffusion permeability [304]. This effect is determined by the ion concentration gradient, which complicates their transfer in one of the directions [305]. This phenomenon can be used to improve the selectivity of electrodialysis [306].

Surface modification by deposition of layers containing fixed ions of opposite charge is very often used to increase the selectivity of membranes to mono- and multicharged ions [300,302,306-310]. For this purpose, surface properties such as hydrophilicity, porosity, nature or concentration of functional groups can be changed [311-314]. However, the layer-by-layer (LBL) modification, described in detail in recent reviews [55,56], increasing the selectivity of transport of ions with different charge sizes, has been considered the most promising. In recent years, this approach has been widely used to create membranes for selective separation of a number of singly and doubly charged ions [309,315-324]. Their use permits to achieve outstanding separation ratios and developing highly efficient electrodialysis. For example, the modification of Nafion membranes made it possible to achieve a separation coefficient of $\mathrm{K}^{+}$and $\mathrm{Mg}^{2+}$ ions in electrodialysis plants exceeding 1000 [320]. However, in this case, the membrane resistance increases by a factor of 20, and the limiting current drops by more than four times. Coating of the layers on the surface of AEM by electric-pulse deposition method increased the separation efficiency of $\mathrm{Cl}^{-} / \mathrm{SO}_{4}{ }^{2-}$ from 8.93 to $94.4 \%$, while the permselectivity increased from 0.81 to 47 . However, a simultaneous increase in membrane resistance should be noted [325]. Nafion ${ }^{\circledR}$ membranes coated with polystyrene sulfate and polyaniline showed a very high selectivity for the electrodialysis separation of $\mathrm{Li}^{+} / \mathrm{Co}^{2+}$ and $\mathrm{K}^{+} / \mathrm{La}^{3+}$ pairs; the separation coefficients exceeded 5000 with a decrease in the limiting current by several hundred times [326]. This approach can also be used to increase the selectivity of separation of ions of the same charge with the use of complexation. Thus, Kazemabad et al. succeeded in increasing the $\mathrm{Li}^{+} / \mathrm{K}^{+}$selectivity of membranes using polyanionite modified with crown ethers with a multilayer composition [327]. However, due to the availability of recent detailed reviews and limited space in this publication, we will consider only some theoretical aspects of this phenomenon. Experiments and mathematical modelling show that the main role in increasing selectivity is played by the first surface bilayer $[316,317,319]$. However, the deposition of additional bilayers continues to increase the specific selectivity up to 10 bilayers [319].

\section{Compromise between the Specific Permselectivity and Permeability. Impact of Concentration Polarization}

For the membranes selective for monovalent ions, as well as for other types of membranes [80-82,328], there is a compromise between selectivity and the flux of the target component. As Table 3 shows, the higher the density of the ion flux through the membranes, the less specific permselectivity. In particular, the greater the driving force (voltage/current in the case of IEMs or pressure in the case of nanofiltration (NF) membranes), the less specific permselectivity in most cases. In a number of works [52,281,319,320,329-333], the IEM selective permeability significantly decreases with current density increasing and practically disappears when the limiting current density is reached. One of the reasons for the decrease in selective permeability is that the control of mass transfer passes from the membrane to the diffusion layer when approaching the limiting state $[281,329,330]$. Another reason is water splitting (generation of $\mathrm{H}^{+}$and $\mathrm{OH}^{-}$ions). To increase specific permselectivity, the formation of bi-layer structure on the membrane surface is quite effective [319]. However, the intensity of water splitting increases with an increase of the number of bi-layers because of increasing the number of bipolar junctions $[319,320]$. This reduces the transfer of the target ion. In addition, the change in $\mathrm{pH}$ in the diffusion layer caused by water splitting can affect the properties of the modifying layer [52,320]. 
Thus, an increase in its swelling and a decrease in charge density can significantly reduce the effect of monovalent permselectivity.

Table 3. The estimations of the specific permselectivity and ionic flux densities for various membranes.

\begin{tabular}{|c|c|c|c|c|}
\hline Membrane & $\begin{array}{l}\text { Flux Density, j, } \\
\text { mol } \cdot h^{-1} \cdot \mathrm{m}^{-2}\end{array}$ & Selectivity & Driving Force & Reference \\
\hline $\begin{array}{l}\text { Biological } \\
\text { membrane }\end{array}$ & $\mathrm{j}\left(\mathrm{K}^{+}\right)-6$ & $\mathrm{~K}^{+} / \mathrm{Na}^{+}>1000$ & Diffusion & [334] \\
\hline $\begin{array}{l}\text { Membrane } 1 \\
\quad(N F-270)\end{array}$ & $\mathrm{j}\left(\mathrm{K}^{+}\right)=2.5$ & $\mathrm{~K}^{+} / \mathrm{Mg}^{2+}<2$ & $\begin{array}{l}\text { Pressure } \\
28 \text { bar }\end{array}$ & [335] \\
\hline Membrane 2 (LLC) & $\mathrm{j}\left(\mathrm{K}^{+}\right)=1.3 \times 10^{-4}$ & $\mathrm{~K}^{+} / \mathrm{Mg}^{2+}-33$ & $\begin{array}{l}\text { Pressure } \\
28 \text { bar }\end{array}$ & [335] \\
\hline $\begin{array}{l}\text { Track-etched } \\
\text { membrane PET } \\
\text { Lumirror }^{\circledR}\end{array}$ & $\begin{array}{l}\mathrm{j}\left(\mathrm{K}^{+}\right)=13.9 \\
\text { in } 1 \mathrm{M} \mathrm{NaCl}\end{array}$ & $\mathrm{K}^{+} / \mathrm{Mg}^{2+}=135$ & $\begin{array}{l}\text { Voltage } \\
10 \mathrm{~V}\end{array}$ & [336] \\
\hline $\begin{array}{l}\text { Zwitterionic } \\
\text { Polyelectrolyte } \\
\text { (SBQAPPO) }\end{array}$ & $\begin{array}{c}\mathrm{j}\left(\mathrm{Na}^{+}\right)=0.67 \text { in } 0.1 \\
\mathrm{M} \mathrm{NaCl}+0.1 \mathrm{M} \\
\mathrm{MgCl}_{2}\end{array}$ & $\begin{array}{c}\mathrm{Na}^{+} / \mathrm{Mg}^{2+}=7.4 \\
\mathrm{H}^{+} / \mathrm{Zn}^{2+}=23.5\end{array}$ & $\begin{array}{l}\text { Current density } 14 \\
\qquad \mathrm{~mA} \mathrm{~cm}^{-2}\end{array}$ & [337] \\
\hline Membrane MK-40 & $\mathrm{j}\left(\mathrm{Na}^{+}\right) \approx 100$ in $1 \mathrm{M}$ & $\begin{array}{l}\text { No specific } \\
\text { selectivity }\end{array}$ & $\begin{array}{c}\text { Voltage } 0.5 \mathrm{~V} \\
i=i_{\lim }=250 \\
\mathrm{~mA} \cdot \mathrm{cm}^{-2}\end{array}$ & unpublished data \\
\hline
\end{tabular}

Quite interesting is the "odd-even" effect of the LBL modified membranes. Abdu et al. [319] describe the case where a CMX cation-exchange membrane was coated by several bilayers of a hyperbranched poly(ethyleneimine) (PEI) bearing positive fixed charges, then by a poly(4-styrenesulfonate) (PSS) layer bearing negative fixed charges (of the same sign as those of the CMX). The specific permselectivity and water splitting were higher in the cases of PEI-terminated bilayers as compared to their values for the PSS-terminated bilayers. Thus, changing the nature of the terminating layer allows switching on and turning off water splitting at the surface of IEMs [7].

To understand the effect of the value of driving force on the membrane specific permselectivity, it is necessary to take into account the current-induced concentration polarization of IEMs in mixed solutions. Mathematical modeling of ion transfer through IEMs in a mixture of several electrolytes was considered in a number of studies [330,332,338-340]. For the first time, the dependence of the effective transport numbers of competing ions in a membrane system on the current density was described by Oren and Litan [338]. The authors used the Nernst-Planck equations and the electroneutrality condition written for three types of ions in the membrane and in the diffusion layers adjacent to it. Both diffusion and migration contributions to the ion transport were taken into account in the diffusion layers, and only ion migration in the membrane. A similar model was developed in [330], where both migration and diffusion transport in the membrane were accounted for. It was shown $[316,340]$ that the loss of specific selectivity with increasing current is due to the transition of mass transfer control from the membrane at low currents to the depleted diffusion layer at the currents close to the limiting one. At low currents, the external concentration polarization (deviations of the concentrations from equilibrium in the diffusion layers) is insignificant, and the effective transport numbers of ions are determined by their migration transport numbers in the membrane. With increasing current, the ion concentration in the diffusion layers changes in such a way that the concentration of the selectively transferred counterion (marked as ion 1 in Figure 8) in the depleted diffusion layer decreases much more than the concentration of the competing counterion (ion 2 in Figure 8). Symmetrically, in the enriched diffusion layer, the concentration of the selectively transferred counterion 1 increases more strongly than that of its competitor. As a result, the concentration profiles in the membrane are arranged in such a way that the diffusion flux of the selectively transported counterion is directed opposite to the migration flux, and the diffusion flux of its competitor, on the contrary, is aligned with the migration flux (Figure 8). As a result, concentration polarization, developing with increasing current, 
restricts the resulting flux of the preferentially transported counterion, and enhances the flux of the competing counterion.

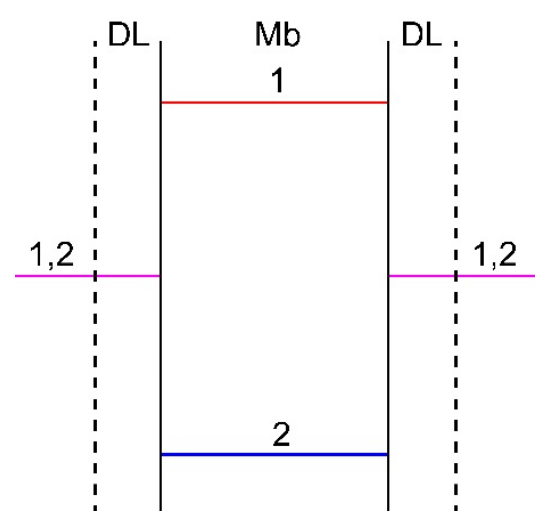

(a)

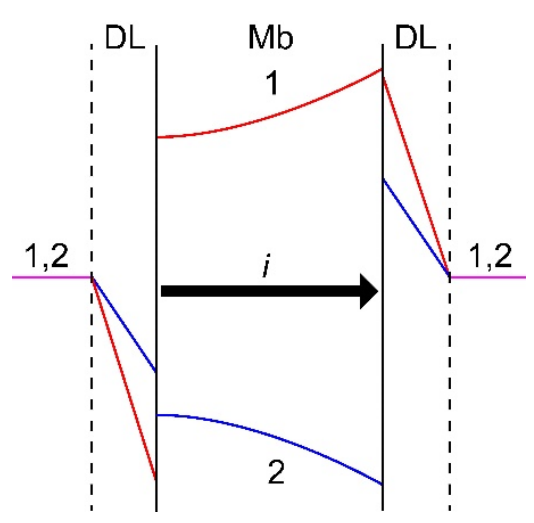

(b)

Figure 8. Scheme of concentration profiles in diffusion layers (DL) and a membrane (Mb) established at zero current (a) and a current density $i$ close to $0.5 i_{\lim }(\mathbf{b})$. Counterion 1 is preferably sorbed by and transferred through the membrane as compared to counterion 2 . The profiles match the results of calculation using model [330]. Explanations are given in the text.

At the limiting current, the mass transfer control passes to the depleted diffusion layer, the concentrations of all ions become zero at the membrane surface facing this diffusion layer. In this approximation, the partial current density of counterion $k, i_{k \lim }$, at $i=i_{\mathrm{lim}}$, can be calculated as follows [330]:

$$
i_{k \lim }=\frac{F}{\delta} D_{k} z_{k} c_{k}^{o}\left(1+\frac{z_{k}}{z_{3}}\right)
$$

where $D_{k}, z_{k}$ and $c_{k}^{0}$ are the diffusion coefficient, charge number and bulk concentration of ion $k(k=1,2)$, respectively; $\delta$ is the diffusion layer thickness, $F$, the Faraday constant; subscript " 3 " refers to the coion, which is common to the considered ternary electrolyte.

There are some papers developing the described models. Fila and Bouzek [332,339] consider also an IEM and two adjacent diffusion layers, but they use the extended Nernst-Planck equation, which contains the convective term. Taking into account the electroosmotic convective transport is important when studying the ion transfer in multi-ionic concentrated solutions, in particular, the application of IEMs in chlor-alkali electrolysis. Geraldes and Afonso [339] applied a linearized form of the Nernst-Planck equations for the same three-layer system with a multicomponent solution. The authors obtained an expression for the limiting current density involving a mass-transfer coefficient and an effective diffusion coefficient of the multi-ionic electrolyte.

The fact that the specific permselectivity depends on the current density makes obvious the problem of optimization of the conditions for the separation of different kinds of ions with the same sign of charge. In the case of a mono-layer membrane, the situation is relatively simple: there are two films, a membrane and a depleted diffusion layer, which can control the mass transfer kinetics. With increasing current, the control passes from the membrane to the diffusion layer. However, in the case of multi-layer membranes, different membrane layers can be limiting; the dependence of the permselectivity on the current density and other experimental conditions may be complicated. These systems seem quite promising but remain poorly studied.

\section{Conclusions}

The above material indicates that the transport properties of ion-exchange membranes are determined primarily by their structure, which in its turn depends on the membrane preparation 
method. As shown in a number of publications, there is a trade-off between the membrane permeability/conductivity and the selectivity of the transfer rate of the target component. In this regard, the quality of membrane material can be characterized by means of the relation between the permeability and permselectivity, for example, by the relation between the ionic conductivity and counterion transport number (in electrodialysis) or ionic conductivity and permeability of fuel molecules (crossover in fuel cells). To enhance this relation, a wide range of approaches is used, such as crosslinking, preparation of hybrid membranes with embedded nanoparticles, and surface modification. Their use can significantly increase the selectivity of transport processes. For example, cross-linking can significantly reduce coion transport, doping with nanoparticles can increase ionic conductivity or, conversely, selectivity of transport processes. A very interesting approach is the surface modification, which allows one to achieve the separation of mono- and multivalent ions. A group of synthetic methods that make it possible to eliminate the formation of large membrane pores during the synthesis (obtaining grafted membranes or membranes with a fairly rigid three-dimensional matrix) should be separately noted.

The use of these approaches offers opportunity for expanding the prospects of ion-exchange membrane use in such a traditional application as electrodialysis, or in rapidly developing hydrogen energy. On the other hand, surface modification can significantly increase the efficiency of extracting valuable components from natural or waste-water.

Funding: This work was supported by IGIC RAS state assignment.

Conflicts of Interest: The authors declare no conflict of interest.

\section{References}

1. Strathmann, H.; Grabowski, A.; Eigenberger, G. Ion-Exchange Membranes in the Chemical Process Industry. Ind. Eng. Chem. Res. 2013, 52, 10364-10379. [CrossRef]

2. Wenten, I.G.; Khoiruddin, K.; Aryanti, P.T.P.; Hakim, A.N. Scale-up Strategies for Membrane-Based Desalination Processes: A Review. J. Membr. Sci. Res. 2016, 2, 42-58. [CrossRef]

3. Ran, J.; Wu, L.; He, Y.; Yang, Z.; Wang, Y.; Jiang, C.; Ge, L.; Bakangura, E.; Xu, T. Ion exchange membranes: New developments and applications. J. Membr. Sci. 2017, 522, 267-291. [CrossRef]

4. Campione, A.; Gurreri, L.; Ciofalo, M.; Micale, G.; Tamburini, A.; Cipollina, A. Electrodialysis for water desalination: A critical assessment of recent developments on process fundamentals, models and applications. Desalination 2018, 434, 121-160. [CrossRef]

5. Apel, P.Y.; Bobreshova, O.V.; Volkov, A.V.; Volkov, V.V.; Nikonenko, V.V.; Stenina, I.A.; Filippov, A.N.; Yampolskii, Y.P.; Yaroslavtsev, A.B. Prospects of Membrane Science Development. Membr. Membr. Technol. 2019, 1, 45-63. [CrossRef]

6. Stenina, I.A.; Yaroslavtsev, A.B. Nanomaterials for lithium-ion batteries and hydrogen energy. Pure Appl. Chem. 2017, 89, 1185-1194. [CrossRef]

7. Ramaswamy, N.; Mukerjee, S. Alkaline Anion-Exchange Membrane Fuel Cells: Challenges in Electrocatalysis and Interfacial Charge Transfer. Chem. Rev. 2019, 119, 11945-11979. [CrossRef] [PubMed]

8. Esmaeili, N.; Gray, E.M.; Webb, C.J. Non-Fluorinated Polymer Composite Proton Exchange Membranes for Fuel Cell Applications-A Review. ChemPhysChem 2019, 20, 2016-2053. [CrossRef] [PubMed]

9. Kalathil, A.; Raghavan, A.; Kandasubramanian, B. Polymer Fuel Cell Based on Polybenzimidazole Membrane: A Review. Polym. Technol. Mater. 2019, 58, 465-497. [CrossRef]

10. Voropaeva, D.Y.; Novikova, S.A.; Kulova, T.L.; Yaroslavtsev, A.B. Conductivity of Nafion-117 membranes intercalated by polar aprotonic solvents. Ionics (Kiel) 2018, 24, 1685-1692. [CrossRef]

11. Chen, X.; Vereecken, P.M. Solid and Solid-Like Composite Electrolyte for Lithium Ion Batteries: Engineering the Ion Conductivity at Interfaces. Adv. Mater. Interfaces 2019, 6, 1800899. [CrossRef]

12. Costa, C.M.; Lee, Y.-H.; Kim, J.-H.; Lee, S.-Y.; Lanceros-Méndez, S. Recent advances on separator membranes for lithium-ion battery applications: From porous membranes to solid electrolytes. Energy Storage Mater. 2019, 22, 346-375. [CrossRef] 
13. Mei, Y.; Tang, C.Y. Recent developments and future perspectives of reverse electrodialysis technology: A review. Desalination 2018, 425, 156-174. [CrossRef]

14. Tufa, R.A.; Pawlowski, S.; Veerman, J.; Bouzek, K.; Fontananova, E.; di Profio, G.; Velizarov, S.; Crespo, J.G.; Nijmeijer, K.; Curcio, E. Progress and prospects in reverse electrodialysis for salinity gradient energy conversion and storage. Appl. Energy 2018, 225, 290-331. [CrossRef]

15. Hong, J.G.; Zhang, B.; Glabman, S.; Uzal, N.; Dou, X.; Zhang, H.; Wei, X.; Chen, Y. Potential ion exchange membranes and system performance in reverse electrodialysis for power generation: A review. J. Membr. Sci. 2015, 486, 71-88. [CrossRef]

16. Safronova, E.Y.; Yaroslavtsev, A.B. Prospects of practical application of hybrid membranes. Pet. Chem. 2016, 56, 281-293. [CrossRef]

17. Li, X.; Zhang, H.; Mai, Z.; Zhang, H.; Vankelecom, I. Ion exchange membranes for vanadium redox flow battery (VRB) applications. Energy Environ. Sci. 2011, 4, 1147-1160. [CrossRef]

18. Shi, Y.; Eze, C.; Xiong, B.; He, W.; Zhang, H.; Lim, T.M.; Ukil, A.; Zhao, J. Recent development of membrane for vanadium redox flow battery applications: A review. Appl. Energy 2019, 238, 202-224. [CrossRef]

19. Sheng, J.; Mukhopadhyay, A.; Wang, W.; Zhu, H. Recent advances in the selective membrane for aqueous redox flow batteries. Mater. Today Nano 2019, 7, 100044. [CrossRef]

20. Faiz, R.; Li, K. Olefin/paraffin separation using membrane based facilitated transport/chemical absorption techniques. Chem. Eng. Sci. 2012, 73, 261-284. [CrossRef]

21. Pedram, S.; Kaghazchi, T.; Ravanchi, M.T. Performance and Energy Consumption of Membrane-Distillation Hybrid Systems for Olefin-Paraffin Separation. Chem. Eng. Technol. 2014, 37, 587-596. [CrossRef]

22. Campos, A.C.C.; dos Reis, R.A.; Ortiz, A.; Gorri, D.; Ortiz, I. A Perspective of Solutions for Membrane Instabilities in Olefin/Paraffin Separations: A Review. Ind. Eng. Chem. Res. 2018, 57, 10071-10085. [CrossRef]

23. Zhilyaeva, N.; Mironova, E.; Ermilova, M.; Orekhova, N.; Dyakova, M.; Shevlyakova, N.; Tverskoii, V.; Yaroslavtsev, A. Facilitated transport of ethylene through the polyethylene-graft-sulfonated polystyrene membranes. The role of humidity. Sep. Purif. Technol. 2018, 195, 170-173. [CrossRef]

24. de Miranda, D.M.V.; da Dutra, L.S.; Way, D.; Amaral, N.; Wegenast, F.; Scaldaferri, M.C.; Jesus, N.; Pinto, J.C. A Bibliometric Survey of Paraffin/Olefin Separation Using Membranes. Membranes (Basel) 2019, 9, 157. [CrossRef]

25. Kim, H.S.; Bae, J.Y.; Park, S.J.; Lee, H.; Bae, H.W.; Kang, S.O.; Lee, S.D.; Choi, D.K. Separation of Olefin/Paraffin Mixtures Using Zwitterionic Silver Complexes as Transport Carriers. Chem. Eur. J. 2007, 13, 2655-2660. [CrossRef]

26. Tomé, L.C.; Mecerreyes, D.; Freire, C.S.R.; Rebelo, L.P.N.; Marrucho, I.M. Polymeric ionic liquid membranes containing $\mathrm{IL}-\mathrm{Ag}^{+}$for ethylene/ethane separation via olefin-facilitated transport. J. Mater. Chem. A 2014, 2, 5631. [CrossRef]

27. Uragami, T. Carrier Transport. In Science and Technology of Separation Membranes; Wiley Online Books; John Wiley \& Sons, Ltd.: Chichester, UK, 2017; pp. 587-634. ISBN 9781118932551.

28. Ahmed, M.; Dincer, I. A review on methanol crossover in direct methanol fuel cells: Challenges and achievements. Int. J. Energy Res. 2011, 35, 1213-1228. [CrossRef]

29. Ji, Y.; Luo, H.; Geise, G.M. Specific co-ion sorption and diffusion properties influence membrane permselectivity. J. Membr. Sci. 2018, 563, 492-504. [CrossRef]

30. Zhao, Y.; Liu, Y.; Ortega, E.; Van der Bruggen, B. Prospects of nanocomposite membranes for water treatment by electrodriven membrane processes. In Nanocomposite Membranes for Water and Gas Separation; Elsevier: Amsterdam, The Netherlands, 2020; pp. 321-354.

31. Nagarale, R.K.; Gohil, G.S.; Shahi, V.K. Recent developments on ion-exchange membranes and electro-membrane processes. Adv. Colloid Interface Sci. 2006, 119, 97-130. [CrossRef]

32. Nikonenko, V.V.; Yaroslavtsev, A.B.; Pourcelly, G. Ion Transfer in and Through Charged Membranes: Structure, Properties, and Theory. In Ionic Interactions in Natural and Synthetic Macromolecules; John Wiley \& Sons, Inc.: Hoboken, NJ, USA, 2012; pp. 267-335. ISBN 9781118165850.

33. Yan, X.; Zheng, W.; Ruan, X.; Pan, Y.; Wu, X.; He, G. The control and optimization of macro/micro-structure of ion conductive membranes for energy conversion and storage. Chin. J. Chem. Eng. 2016, 24, 558-571. [CrossRef]

34. Mondal, S.; Griffiths, I.M.; Ramon, G.Z. Forefronts in structure-performance models of separation membranes. J. Membr. Sci. 2019, 588, 117166. [CrossRef] 
35. Kononenko, N.; Nikonenko, V.; Grande, D.; Larchet, C.; Dammak, L.; Fomenko, M.; Volfkovich, Y. Porous structure of ion exchange membranes investigated by various techniques. Adv. Colloid Interface Sci. 2017, 246, 196-216. [CrossRef] [PubMed]

36. Pismenskaya, N.D.; Pokhidnia, E.V.; Pourcelly, G.; Nikonenko, V.V. Can the electrochemical performance of heterogeneous ion-exchange membranes be better than that of homogeneous membranes? J. Membr. Sci. 2018, 566, 54-68. [CrossRef]

37. Miao, Y.; Jia, Y.; Guo, R.; Wang, M. Heterogeneous anion-exchange membrane: Influences of charged binders with crosslinking structure on electrodialytic performance. J. Membr. Sci. 2018, 557, 67-75. [CrossRef]

38. Zabolotskii, V.; Sheldeshov, N.; Melnikov, S. Heterogeneous bipolar membranes and their application in electrodialysis. Desalination 2014, 342, 183-203. [CrossRef]

39. Drioli, E.; Criscuoli, A.; Macedonio, F. Membrane Based Desalination: An. Integrated Approach; Iwa Publishing: London, UK, 2011; ISBN 1843393212.

40. Arar, Ö.; Yüksel, Ü.; Kabay, N.; Yüksel, M. Various applications of electrodeionization (EDI) method for water treatment-A short review. Desalination 2014, 342, 16-22. [CrossRef]

41. Galama, A.H.; Daubaras, G.; Burheim, O.S.; Rijnaarts, H.H.M.; Post, J.W. Seawater electrodialysis with preferential removal of divalent ions. J. Membr. Sci. 2014, 452, 219-228. [CrossRef]

42. Noguchi, M.; Nakamura, Y.; Shoji, T.; Iizuka, A.; Yamasaki, A. Simultaneous removal and recovery of boron from waste water by multi-step bipolar membrane electrodialysis. J. Water Process. Eng. 2018, 23, $299-305$. [CrossRef]

43. Koseoglu-Imer, D.Y.; Karagunduz, A. Recent developments of electromembrane desalination processes. Environ. Technol. Rev. 2018, 7, 199-219. [CrossRef]

44. Damtie, M.M.; Woo, Y.C.; Kim, B.; Hailemariam, R.H.; Park, K.-D.; Shon, H.K.; Park, C.; Choi, J.-S. Removal of fluoride in membrane-based water and wastewater treatment technologies: Performance review. J. Environ. Manag. 2019, 251, 109524. [CrossRef]

45. Younis, S.A.; Maitlo, H.A.; Lee, J.; Kim, K.-H. Nanotechnology-based sorption and membrane technologies for the treatment of petroleum-based pollutants in natural ecosystems and wastewater streams. Adv. Colloid Interface Sci. 2020, 275, 102071. [CrossRef] [PubMed]

46. Iizuka, A.; Yamashita, Y.; Nagasawa, H.; Yamasaki, A.; Yanagisawa, Y. Separation of lithium and cobalt from waste lithium-ion batteries via bipolar membrane electrodialysis coupled with chelation. Sep. Purif. Technol. 2013, 113, 33-41. [CrossRef]

47. Jiang, C.; Chen, H.; Zhang, Y.; Feng, H.; Shehzad, M.A.; Wang, Y.; Xu, T. Complexation Electrodialysis as a general method to simultaneously treat wastewaters with metal and organic matter. Chem. Eng. J. 2018, 348, 952-959. [CrossRef]

48. Gmar, S.; Chagnes, A. Recent advances on electrodialysis for the recovery of lithium from primary and secondary resources. Hydrometallurgy 2019, 189, 105124. [CrossRef]

49. Liu, Y.; Ke, X.; Zhu, H.; Chen, R.; Chen, X.; Zheng, X.; Jin, Y.; Van der Bruggen, B. Treatment of raffinate generated via copper ore hydrometallurgical processing using a bipolar membrane electrodialysis system. Chem. Eng. J. 2020, 382, 122956. [CrossRef]

50. İpekçi, D.; Kabay, N.; Bunani, S.; Altık, E.; Arda, M.; Yoshizuka, K.; Nishihama, S. Application of heterogeneous ion exchange membranes for simultaneous separation and recovery of lithium and boron from aqueous solution with bipolar membrane electrodialysis (EDBM). Desalination 2020, 479, 114313. [CrossRef]

51. Reig, M.; Farrokhzad, H.; Van der Bruggen, B.; Gibert, O.; Cortina, J.L. Synthesis of a monovalent selective cation exchange membrane to concentrate reverse osmosis brines by electrodialysis. Desalination 2015, 375, 1-9. [CrossRef]

52. Roghmans, F.; Evdochenko, E.; Martí-Calatayud, M.C.; Garthe, M.; Tiwari, R.; Walther, A.; Wessling, M. On the permselectivity of cation-exchange membranes bearing an ion selective coating. J. Membr. Sci. 2020, 600, 117854. [CrossRef]

53. Pang, X.; Tao, Y.; Xu, Y.; Pan, J.; Shen, J.; Gao, C. Enhanced monovalent selectivity of cation exchange membranes via adjustable charge density on functional layers. J. Membr. Sci. 2020, 595, 117544. [CrossRef]

54. Zhang, Y.; Wang, L.; Sun, W.; Hu, Y.; Tang, H. Membrane technologies for $\mathrm{Li}^{+} / \mathrm{Mg}^{2+}$ separation from salt-lake brines and seawater: A comprehensive review. J. Ind. Eng. Chem. 2020, 81, 7-23. [CrossRef] 
55. Ge, L.; Wu, B.; Yu, D.; Mondal, A.N.; Hou, L.; Afsar, N.U.; Li, Q.; Xu, T.; Miao, J.; Xu, T. Monovalent cation perm-selective membranes (MCPMs): New developments and perspectives. Chin. J. Chem. Eng. 2017, 25, 1606-1615. [CrossRef]

56. Luo, T.; Abdu, S.; Wessling, M. Selectivity of ion exchange membranes: A review. J. Membr. Sci. 2018, 555, 429-454. [CrossRef]

57. Besha, A.T.; Tsehaye, M.T.; Aili, D.; Zhang, W.; Tufa, R.A. Design of Monovalent Ion Selective Membranes for Reducing the Impacts of Multivalent Ions in Reverse Electrodialysis. Membranes (Basel) 2019, 10, 7. [CrossRef] [PubMed]

58. Merle, G.; Wessling, M.; Nijmeijer, K. Anion exchange membranes for alkaline fuel cells: A review. J. Membr. Sci. 2011, 377, 1-35. [CrossRef]

59. Mauritz, K.A.; Moore, R.B. State of understanding of Nafion. Chem. Rev. 2004, 104, 4535-4585. [CrossRef] [PubMed]

60. Kusoglu, A.; Weber, A.Z. New Insights into Perfluorinated Sulfonic-Acid Ionomers. Chem. Rev. 2017, 117, 987-1104. [CrossRef]

61. Giffin, G.A.; Haugen, G.M.; Hamrock, S.J.; Di Noto, V. Interplay between structure and relaxations in perfluorosulfonic acid proton conducting membranes. J. Am. Chem. Soc. 2013, 135, 822-834. [CrossRef]

62. Yaroslavtsev, A.B. Perfluorinated ion-exchange membranes. Polym. Sci. Ser. A 2013, 55, 674-698. [CrossRef]

63. Bordín, S.P.F.; Andrada, H.E.; Carreras, A.C.; Castellano, G.E.; Oliveira, R.G.; Josa, V.M.G. Nafion membrane channel structure studied by small-angle X-ray scattering and Monte Carlo simulations. Polymer (Guildf) 2018, 155, 58-63. [CrossRef]

64. Yin, C.; Li, J.; Zhou, Y.; Zhang, H.; Fang, P.; He, C. Phase Separation and Development of Proton Transport Pathways in Metal Oxide Nanoparticle/Nafion Composite Membranes during Water Uptake. J. Phys. Chem. C 2018, 122, 9710-9717. [CrossRef]

65. Sollner, K. The Electrochemistry of Porous Membranes, with Particular Reference to Ion Exchange Membranes and Their Use in Model Studies of Biophysical Interest. J. Macromol. Sci. Part A Chem. 1969, 3, 1-86. [CrossRef]

66. Tian, H.; Wang, Y.; Pei, Y.; Crittenden, J.C. Unique applications and improvements of reverse electrodialysis: A review and outlook. Appl. Energy 2020, 262, 114482. [CrossRef]

67. Yaroslavtsev, A.B. Correlation between the properties of hybrid ion-exchange membranes and the nature and dimensions of dopant particles. Nanotechnol. Russ. 2012, 7, 437-451. [CrossRef]

68. Golubenko, D.V.; Safronova, E.Y.; Ilyin, A.B.; Shevlyakov, N.V.; Tverskoi, V.A.; Pourcelly, G.; Yaroslavtsev, A.B. Water state and ionic conductivity of grafted ion exchange membranes based on polyethylene and sulfonated polystyrene. Mendeleev Commun. 2017, 27, 380-381. [CrossRef]

69. Golubenko, D.V.; Safronova, E.Y.; Ilyin, A.B.; Shevlyakova, N.V.; Tverskoi, V.A.; Dammak, L.; Grande, D.; Yaroslavtsev, A.B. Influence of the water state on the ionic conductivity of ion-exchange membranes based on polyethylene and sulfonated grafted polystyrene. Mater. Chem. Phys. 2017, 197, 192-199. [CrossRef]

70. Thompson, E.L.; Capehart, T.W.; Fuller, T.J.; Jorne, J. Investigation of low-temperature proton transport in Nafion using direct current conductivity and differential scanning calorimetry. J. Electrochem. Soc. 2006, 153, A2351-A2362. [CrossRef]

71. Mendil-Jakani, H.; Davies, R.J.; Dubard, E.; Guillermo, A.; Gebel, G. Water crystallization inside fuel cell membranes probed by X-ray scattering. J. Membr. Sci. 2011, 369, 148-154. [CrossRef]

72. Siu, A.; Schmeisser, J.; Holdcroft, S. Effect of Water on the Low Temperature Conductivity of Polymer Electrolytes. J. Phys. Chem. B 2006, 110, 6072-6080. [CrossRef]

73. Lue, S.J.; Shieh, S.-J. Water States in Perfluorosulfonic Acid Membranes Using Differential Scanning Calorimetry. J. Macromol. Sci. Part B 2009, 48, 114-127. [CrossRef]

74. Escoubes, M.; Pineri, M.; Robens, E. Application of coupled thermal analysis techniques to thermodynamic studies of water interactions with a compressible ionic polymer matrix. Thermochim. Acta 1984, 82, 149-160. [CrossRef]

75. Lin, J.; Wu, P.-H.; Wycisk, R.; Pintauro, P.N.; Shi, Z. Properties of Water in Prestretched Recast Nafion. Macromolecules 2008, 41, 4284-4289. [CrossRef]

76. Plazanet, M.; Sacchetti, F.; Petrillo, C.; Demé, B.; Bartolini, P.; Torre, R. Water in a polymeric electrolyte membrane: Sorption/desorption and freezing phenomena. J. Membr. Sci. 2014, 453, 419-424. [CrossRef]

77. Hwang, G.S.; Parkinson, D.Y.; Kusoglu, A.; MacDowell, A.A.; Weber, A.Z. Understanding Water Uptake and Transport in Nafion Using X-ray Microtomography. ACS Macro Lett. 2013, 2, 288-291. [CrossRef] 
78. Vishnyakov, A.; Neimark, A.V. Self-Assembly in Nafion Membranes upon Hydration: Water Mobility and Adsorption Isotherms. J. Phys. Chem. B 2014, 118, 11353-11364. [CrossRef]

79. Kononenko, N.A.; Fomenko, M.A.; Volfkovich, Y.M. Structure of perfluorinated membranes investigated by method of standard contact porosimetry. Adv. Colloid Interface Sci. 2015, 222, 425-435. [CrossRef] [PubMed]

80. Hammer, R.; Schönhoff, M.; Hansen, M.R. Comprehensive Picture of Water Dynamics in Nafion Membranes at Different Levels of Hydration. J. Phys. Chem. B 2019, 123, 8313-8324. [CrossRef]

81. Geise, G.M.; Hickner, M.A.; Logan, B.E. Ionic resistance and permselectivity tradeoffs in anion exchange membranes. ACS Appl. Mater. Interfaces 2013, 5, 10294-10301. [CrossRef]

82. Cho, D.H.; Lee, K.H.; Kim, Y.M.; Park, S.H.; Lee, W.H.; Lee, S.M.; Lee, Y.M. Effect of cationic groups in poly(arylene ether sulfone) membranes on reverse electrodialysis performance. Chem. Commun. 2017, 53, 2323-2326. [CrossRef]

83. Park, H.B.; Kamcev, J.; Robeson, L.M.; Elimelech, M.; Freeman, B.D. Maximizing the right stuff: The trade-off between membrane permeability and selectivity. Science 2017, 356, eaab0530. [CrossRef]

84. Golubenko, D.V.; Pourcelly, G.; Yaroslavtsev, A.B. Permselectivity and ion-conductivity of grafted cation-exchange membranes based on UV-oxidized polymethylpenten and sulfonated polystyrene. Sep. Purif. Technol. 2018, 207, 329-335. [CrossRef]

85. Robeson, L.M. The upper bound revisited. J. Membr. Sci. 2008, 320, 390-400. [CrossRef]

86. Sanders, D.F.; Smith, Z.P.; Guo, R.; Robeson, L.M.; McGrath, J.E.; Paul, D.R.; Freeman, B.D. Energy-efficient polymeric gas separation membranes for a sustainable future: A review. Polymer (Guildf) 2013, 54, 4729-4761. [CrossRef]

87. Li, P.; Wang, Z.; Qiao, Z.; Liu, Y.; Cao, X.; Li, W.; Wang, J.; Wang, S. Recent developments in membranes for efficient hydrogen purification. J. Membr. Sci. 2015, 495, 130-168. [CrossRef]

88. Xu, J.; Wu, H.; Wang, Z.; Qiao, Z.; Zhao, S.; Wang, J. Recent advances on the membrane processes for $\mathrm{CO}_{2}$ separation. Chin. J. Chem. Eng. 2018, 26, 2280-2291. [CrossRef]

89. Restrepo-Flórez, J.-M.; Maldovan, M. Permeabilities and selectivities in anisotropic planar membranes for gas separations. Sep. Purif. Technol. 2019, 228, 115762. [CrossRef]

90. Yampolskii, Y.; Belov, N.; Alentiev, A. Perfluorinated polymers as materials of membranes for gas and vapor separation. J. Membr. Sci. 2020, 598, 117779. [CrossRef]

91. Irfan, M.; Ge, L.; Wang, Y.; Yang, Z.; Xu, T. Hydrophobic Side Chains Impart Anion Exchange Membranes with High Monovalent-Divalent Anion Selectivity in Electrodialysis. ACS Sustain. Chem. Eng. 2019, 7, 4429-4442. [CrossRef]

92. Li, C.; Wang, G.; Yu, D.; Sheng, F.; Shehzad, M.A.; He, T.; Xu, T.; Ren, X.; Cao, M.; Wu, B.; et al. Cross-linked anion exchange membranes with hydrophobic side-chains for anion separation. J. Membr. Sci. 2019, 581, 150-157. [CrossRef]

93. Jeon, J.Y.; Park, S.; Han, J.; Maurya, S.; Mohanty, A.D.; Tian, D.; Saikia, N.; Hickner, M.A.; Ryu, C.Y.; Tuckerman, M.E.; et al. Synthesis of Aromatic Anion Exchange Membranes by Friedel-Crafts Bromoalkylation and Cross-Linking of Polystyrene Block Copolymers. Macromolecules 2019, 52, 2139-2147. [CrossRef]

94. Thieu, L.M.; Zhu, L.; Korovich, A.G.; Hickner, M.A.; Madsen, L.A. Multiscale Tortuous Diffusion in Anion and Cation Exchange Membranes. Macromolecules 2019, 52, 24-35. [CrossRef]

95. Safronova, E.Y.; Stenina, I.A.; Yaroslavtsev, A.B. The possibility of changing the transport properties of ion-exchange membranes by their treatment. Pet. Chem. 2017, 57, 299-305. [CrossRef]

96. Volkov, V.I.; Volkov, E.V.; Timofeev, S.V.; Sanginov, E.A.; Pavlov, A.A.; Safronova, E.Y.; Stenina, I.A.; Yaroslavtsev, A.B. Water self-diffusion and ionic conductivity in perfluorinated sulfocationic membranes MF-4SK. Russ. J. Inorg. Chem. 2010, 55, 315-317. [CrossRef]

97. Stenina, I.A.; Yaroslavtsev, A.B. Low- and intermediate-temperature proton-conducting electrolytes. Inorg. Mater. 2017, 53, 253-262. [CrossRef]

98. Svoboda, M.; Beneš, J.; Vobecká, L.; Slouka, Z. Swelling induced structural changes of a heterogeneous cation-exchange membrane analyzed by micro-computed tomography. J. Membr. Sci. 2017, 525, 195-201. [CrossRef]

99. Kozmai, A.E.; Nikonenko, V.V.; Zyryanova, S.; Pismenskaya, N.D.; Dammak, L.; Baklouti, L. Modelling of anion-exchange membrane transport properties with taking into account the change in exchange capacity and swelling when varying bathing solution concentration and pH. J. Membr. Sci. 2019, 590, 117291. [CrossRef] 
100. Somovilla, P.; Villaluenga, J.P.G.; Barragán, V.M.; Izquierdo-Gil, M.A. Experimental determination of the streaming potential across cation-exchange membranes with different morphologies. J. Membr. Sci. 2016, 500, 16-24. [CrossRef]

101. Shin, D.W.; Guiver, M.D.; Lee, Y.M. Hydrocarbon-Based Polymer Electrolyte Membranes: Importance of Morphology on Ion Transport and Membrane Stability. Chem. Rev. 2017, 117, 4759-4805. [CrossRef]

102. Barragán, V.M.; Pérez-Haro, M.J. Correlations between water uptake and effective fixed charge concentration at high univalent electrolyte concentrations in sulfonated polymer cation-exchange membranes with different morphology. Electrochim. Acta 2011, 56, 8630-8637. [CrossRef]

103. Akberova, E.M.; Vasil'eva, V.I. Effect of the resin content in cation-exchange membranes on development of electroconvection. Electrochem. Commun. 2020, 111, 106659. [CrossRef]

104. Sarapulova, V.; Shkorkina, I.; Mareev, S.; Pismenskaya, N.; Kononenko, N.; Larchet, C.; Dammak, L.; Nikonenko, V. Transport Characteristics of Fujifilm Ion-Exchange Membranes as Compared to Homogeneous Membranes AMX and CMX and to Heterogeneous Membranes MK-40 and MA-41. Membranes (Basel) 2019, 9, 84. [CrossRef]

105. Sata, T. Properties, Characterization and Microstructure of Ion Exchange Membranes. In Ion Exchange Membranes; Sata, T., Ed.; Royal Society of Chemistry: Cambridge, UK, 2004; pp. 89-134. ISBN 978-0-85404-590-7.

106. Bulejko, P.; Stránská, E. The effect of initial moisture content of cation-exchange resin on the preparation and properties of heterogeneous cation-exchange membranes. Mater. Chem. Phys. 2018, 205, 470-479. [CrossRef]

107. Hwang, H.Y.; Koh, H.C.; Rhim, J.W.; Nam, S.Y. Preparation of sulfonated SEBS block copolymer membranes and their permeation properties. Desalination 2008, 233, 173-182. [CrossRef]

108. Elabd, Y.A.; Hickner, M.A. Block copolymers for fuel cells. Macromolecules 2011, 44, 1-11. [CrossRef]

109. Nishimura, M.; Mizutani, Y. Correlation between structure and properties of cation-exchange membranes prepared by the paste method. J. Appl. Electrochem. 1981, 11, 165-171. [CrossRef]

110. Sata, T. Ion. Exchange Membranes-Preparation, Characterization, Modification and Application; The Royal Society of Chemistry: Cambridge, UK, 2004; ISBN 0854045902.

111. Nasef, M.M.; Hegazy, E.S.A. Preparation and applications of ion exchange membranes by radiation-induced graft copolymerization of polar monomers onto non-polar films. Prog. Polym. Sci. 2004, 29, 499-561. [CrossRef]

112. Nasef, M.M.; Gürsel, S.A.; Karabelli, D.; Güven, O. Radiation-grafted materials for energy conversion and energy storage applications. Prog. Polym. Sci. 2016, 63, 1-41. [CrossRef]

113. Hodgdon, R.B. Polyelectrolytes prepared from perfluoroalkylaryl macromolecules. J. Polym. Sci. Part A-1 Polym. Chem. 1968, 6, 171-191. [CrossRef]

114. Golubenko, D.V.; Yaroslavtsev, A.B. New approach to the preparation of grafted ion exchange membranes based on UV-oxidized polymer films and sulfonated polystyrene. Mendeleev Commun. 2017, 27, 572-573. [CrossRef]

115. Safronova, E.Y.; Golubenko, D.V.; Shevlyakova, N.V.; D’yakova, M.G.; Tverskoi, V.A.; Dammak, L.; Grande, D.; Yaroslavtsev, A.B. New cation-exchange membranes based on cross-linked sulfonated polystyrene and polyethylene for power generation systems. J. Membr. Sci. 2016, 515, 196-203. [CrossRef]

116. Sherazi, T.; Ahmad, S.; Kashmiri, M.; Guiver, M. Radiation-induced grafting of styrene onto ultra-high molecular weight polyethylene powder and subsequent film fabrication for application as polymer electrolyte membranes: I. Influence of grafting conditions. J. Membr. Sci. 2008, 325, 964-972. [CrossRef]

117. Gürsel, S.A.; Youcef, H.B.; Wokaun, A.; Scherer, G.G. Influence of reaction parameters on grafting of styrene into poly(ethylene-alt-tetrafluoroethylene) films. Nucl. Instrum. Methods Phys. Res. Sect. B Beam Interact. Mater. Atoms 2007, 265, 198-203. [CrossRef]

118. Sherazi, T.A.; Ahmad, S.; Kashmiri, M.A.; Kim, D.S.; Guiver, M.D. Radiation-induced grafting of styrene onto ultra-high molecular weight polyethylene powder for polymer electrolyte fuel cell application: II. Sulfonation and characterization. J. Membr. Sci. 2009, 333, 59-67. [CrossRef]

119. Ponomarev, A.N.; Abdrashitov, E.F.; Kritskaya, D.A.; Bokun, V.C.; Sanginov, E.A.; Dobrovol'skii, Y.A. Synthesis of polymer nanocomposite ion-exchange membranes from sulfonated polystyrene and study of their properties. Russ. J. Electrochem. 2017, 53, 589-607. [CrossRef]

120. Zouahri, A.; Assouag, M.; Robin, J.J.; Boutevin, B.; Elbachiri, A.; Elmidaoui, A. Comparative ozonization of LDPE and HDPE and grafting of some monomers to elaborate new ion exchange membranes. J. Appl. Polym. Sci. 2006, 101, 4423-4429. [CrossRef] 
121. Duy, T.T.; Sawada, S.; Hasegawa, S.; Katsumura, Y.; Maekawa, Y. Poly(ethylene-co-tetrafluoroethylene) (ETFE)-based graft-type polymer electrolyte membranes with different ion exchange capacities: Relative humidity dependence for fuel cell applications. J. Membr. Sci. 2013, 447, 19-25. [CrossRef]

122. Chong, F.; Wang, C.; Miao, J.; Xia, R.; Cao, M.; Chen, P.; Yang, B.; Zhou, W.; Qian, J. Preparation and properties of cation-exchange membranes based on commercial chlorosulfonated polyethylene (CSM) for diffusion dialysis. J. Taiwan Inst. Chem. Eng. 2017, 78, 561-565. [CrossRef]

123. Sadeghi, S.; Şanlı, L.I.; Güler, E.; Gürsel, S.A. Enhancing proton conductivity via sub-micron structures in proton conducting membranes originating from sulfonated PVDF powder by radiation-induced grafting. Solid State Ion. 2018, 314, 66-73. [CrossRef]

124. Hasegawa, S.; Hiroki, A.; Ohta, Y.; Iimura, N.; Fukaya, A.; Maekawa, Y. Thermally stable graft-type polymer electrolyte membranes consisting based on poly (ether ether ketone) and crosslinked graft-polymers for fuel cell applications. Radiat. Phys. Chem. 2020, 171, 108647. [CrossRef]

125. Gubler, L.; Gürsel, S.A.; Scherer, G.G. Radiation Grafted Membranes for Polymer Electrolyte Fuel Cells. Fuel Cells 2005, 5, 317-335. [CrossRef]

126. Ma, J.; Peng, J.; Zhai, M. Radiation-Grafted Membranes for Applications in Renewable Energy Technology. In Radiation Technology for Advanced Materials; Wu, G., Zhai, M., Wang, M., Eds.; Elsevier: Amsterdam, The Netherlands, 2019; pp. 207-247. ISBN 978-0-12-814017-8.

127. Golubenko, D.V.; Van der Bruggen, B.; Yaroslavtsev, A.B. Novel anion exchange membrane with low ionic resistance based on chloromethylated/quaternized-grafted polystyrene for energy efficient electromembrane processes. J. Appl. Polym. Sci. 2020, 137, 48656. [CrossRef]

128. Kang, N.; Shin, J.; Hwang, T.S.; Lee, Y.-S. A facile method for the preparation of poly(vinylidene fluoride) membranes filled with cross-linked sulfonated polystyrene. React. Funct. Polym. 2016, 99, 42-48. [CrossRef]

129. Qiu, Q.; Cha, J.-H.; Choi, Y.-W.; Choi, J.-H.; Shin, J.; Lee, Y.-S. Preparation of polyethylene membranes filled with crosslinked sulfonated polystyrene for cation exchange and transport in membrane capacitive deionization process. Desalination 2017, 417, 87-93. [CrossRef]

130. ul Haq, O.; Choi, J.-H.; Lee, Y.-S. Anion-exchange membrane for membrane capacitive deionization prepared via pore-filling polymerization in a porous polyethylene supporting membrane. React. Funct. Polym. 2018, 132, 36-42. [CrossRef]

131. Auclair, B.; Nikonenko, V.; Larchet, C.; Métayer, M.; Dammak, L. Correlation between transport parameters of ion-exchange membranes. J. Membr. Sci. 2001, 195, 89-102. [CrossRef]

132. Willson, T.R.; Hamerton, I.; Varcoe, J.R.; Bance-Soualhi, R. Radiation-grafted cation-exchange membranes: An initial ex situ feasibility study into their potential use in reverse electrodialysis. Sustain. Energy Fuels 2019, 3, 1682-1692. [CrossRef]

133. Chen, J.; Asano, M.; Yamaki, T.; Yoshida, M. Preparation and characterization of chemically stable polymer electrolyte membranes by radiation-induced graft copolymerization of four monomers into ETFE films. J. Membr. Sci. 2006, 269, 194-204. [CrossRef]

134. Sherazi, T.A.; Sohn, J.Y.; Lee, Y.M.; Guiver, M.D. Polyethylene-based radiation grafted anion-exchange membranes for alkaline fuel cells. J. Membr. Sci. 2013, 441, 148-157. [CrossRef]

135. Strasser, D.J.; Graziano, B.J.; Knauss, D.M. Base stable poly(diallylpiperidinium hydroxide) multiblock copolymers for anion exchange membranes. J. Mater. Chem. A 2017, 5, 9627-9640. [CrossRef]

136. Cassady, H.J.; Cimino, E.C.; Kumar, M.; Hickner, M.A. Specific ion effects on the permselectivity of sulfonated poly(ether sulfone) cation exchange membranes. J. Membr. Sci. 2016, 508, 146-152. [CrossRef]

137. Gupta, B.; Büchi, F.N.; Staub, M.; Grman, D.; Scherer, G.G. Cation exchange membranes by pre-irradiation grafting of styrene into FEP films. II. Properties of copolymer membranes. J. Polym. Sci. Part A Polym. Chem. 1996, 34, 1873-1880. [CrossRef]

138. Walsby, N.; Sundholm, F.; Kallio, T.; Sundholm, G. Radiation-grafted ion-exchange membranes: Influence of the initial matrix on the synthesis and structure. J. Polym. Sci. Part A Polym. Chem. 2001, 39, 3008-3017. [CrossRef]

139. Rubatat, L.; Shi, Z.; Diat, O.; Holdcroft, S.; Frisken, B.J. Structural Study of Proton-Conducting Fluorous Block Copolymer Membranes. Macromolecules 2005, 39, 720-730. [CrossRef]

140. Shi, Z.; Holdcroft, S. Synthesis and proton conductivity of partially sulfonated poly([vinylidene difluoride-co-hexafluoropropylene]-b-styrene) block copolymers. Macromolecules 2005, 38, 4193-4201. [CrossRef] 
141. Ponce-González, J.; Whelligan, D.K.; Wang, L.; Bance-Soualhi, R.; Wang, Y.; Peng, Y.; Peng, H.; Apperley, D.C.; Sarode, H.N.; Pandey, T.P.; et al. High performance aliphatic-heterocyclic benzyl-quaternary ammonium radiation-grafted anion-exchange membranes. Energy Environ. Sci. 2016, 9, 3724-3735. [CrossRef]

142. Bergner, D. Membrane cells for chlor-alkali electrolysis. J. Appl. Electrochem. 1982, 12, 631-644. [CrossRef]

143. Sata, T. Application of ion exchange membranes. In Ion Exchange Membranes; Sata, T., Ed.; Royal Society of Chemistry: Cambridge, UK, 2004; pp. 215-302. ISBN 978-0-85404-590-7.

144. Golubenko, D.V.; Voropaeva, D.Y.; Yaroslavtsev, A.B. Cation-exchange membranes with sulfonylimide groups showing a high ionic conductivity in water/organic amide mixed systems. Mater. Lett. 2020, 277, 128247. [CrossRef]

145. Ahn, S.-Y.; Lee, Y.-C.; Ha, H.Y.; Hong, S.-A.; Oh, I.-H. Properties of the reinforced composite membranes formed by melt soluble ion conducting polymer resins for PEMFCs. Electrochim. Acta 2004, 50, 571-575. [CrossRef]

146. Mollá, S.; Compañ, V. Polyvinyl alcohol nanofiber reinforced Nafion membranes for fuel cell applications. J. Membr. Sci. 2011, 372, 191-200. [CrossRef]

147. Křivčík, J.; Neděla, D.; Válek, R. Ion-exchange membrane reinforcing. Desalin. Water Treat. 2014, 3994, 1-6. [CrossRef]

148. Allioux, F.-M.; He, L.; She, F.; Hodgson, P.D.; Kong, L.; Dumée, L.F. Investigation of hybrid ion-exchange membranes reinforced with non-woven metal meshes for electro-dialysis applications. Sep. Purif. Technol. 2015, 147, 353-363. [CrossRef]

149. Lee, Y.J.; Cha, M.S.; Oh, S.-G.; So, S.; Kim, T.-H.; Ryoo, W.S.; Hong, Y.T.; Lee, J.Y. Reinforced anion exchange membrane based on thermal cross-linking method with outstanding cell performance for reverse electrodialysis. RSC Adv. 2019, 9, 27500-27509. [CrossRef]

150. MacDonald, R.J. Anion Selective Polymers Prepared from Concentrated Solutions of N,N'-Methylenebisacrylamide. U.S. Patent No. 5,037,858, 6 August 1991.

151. Lin, J.R.; Mir, L.; Zheng, Y. Styrene Sulfonate Cation Exchange Membrane. U.S. Patent No. 6,221,248, 24 April 2001.

152. Choi, Y.-J.; Kang, M.-S.; Moon, S.-H. A new preparation method for cation-exchange membrane using monomer sorption into reinforcing materials. Desalination 2002, 146, 287-291. [CrossRef]

153. Zaidi, S.M. Polymer Sulfonation A Versatile Route to Prepare Proton-Conducting Membrane Material for Advanced Technologies. Arab. J. Sci. Eng. 2003, 28, 183-194.

154. Kreuer, K. On the development of proton conducting materials for technological applications. Solid State Ion. 1997, 97, 1-15. [CrossRef]

155. Lai, A.N.; Guo, D.; Lin, C.X.; Zhang, Q.G.; Zhu, A.M.; Ye, M.L.; Liu, Q.L. Enhanced performance of anion exchange membranes via crosslinking of ion cluster regions for fuel cells. J. Power Sources 2016, 327, 56-66. [CrossRef]

156. Xu, W.; Zhao, Y.; Yuan, Z.; Li, X.; Zhang, H.; Vankelecom, I.F.J. Highly stable anion exchange membranes with internal cross-linking networks. Adv. Funct. Mater. 2015, 25, 2583-2589. [CrossRef]

157. Cha, M.S.; Lee, J.Y.; Kim, T.-H.; Jeong, H.Y.; Shin, H.Y.; Oh, S.-G.; Hong, Y.T. Preparation and characterization of crosslinked anion exchange membrane (AEM) materials with poly(phenylene ether)-based short hydrophilic block for use in electrochemical applications. J. Membr. Sci. 2017, 530, 73-83. [CrossRef]

158. Hossain, M.M.; Wu, L.; Liang, X.; Yang, Z.; Hou, J.; Xu, T. Anion exchange membrane crosslinked in the easiest way stands out for fuel cells. J. Power Sources 2018, 390, 234-241. [CrossRef]

159. Wang, C.; He, Z.; Xie, X.; Mai, X.; Li, Y.; Li, T.; Zhao, M.; Yan, C.; Liu, H.; Wujcik, E.K.; et al. Controllable Cross-Linking Anion Exchange Membranes with Excellent Mechanical and Thermal Properties. Macromol. Mater. Eng. 2018, 303, 1-8. [CrossRef]

160. Güler, E.; Elizen, R.; Vermaas, D.A.; Saakes, M.; Nijmeijer, K. Performance-determining membrane properties in reverse electrodialysis. J. Membr. Sci. 2013, 446, 266-276. [CrossRef]

161. Kerres, J.; Cui, W.; Junginger, M. Development and characterization of crosslinked ionomer membranes based upon sulfinated and sulfonated PSU. Crosslinked PSU blend membranes by alkylation of sulfinate groups with dihalogenoalkanes. J. Membr. Sci. 1998, 139, 227-241. [CrossRef]

162. Kerres, J.; Zhang, W.; Ullrich, A.; Tang, C.M.; Hein, M.; Gogel, V.; Frey, T.; Jörissen, L. Synthesis and characterization of polyaryl blend membranes having different composition, different covalent and/or ionical cross-linking density, and their application to DMFC. Desalination 2002, 147, 173-178. [CrossRef] 
163. Lee, K.H.; Cho, D.H.; Kim, Y.M.; Moon, S.J.; Seong, J.G.; Shin, D.W.; Sohn, J.Y.; Kim, J.F.; Lee, Y.M. Highly conductive and durable poly(arylene ether sulfone) anion exchange membrane with end-group cross-linking. Energy Environ. Sci. 2017, 10, 275-285. [CrossRef]

164. Chen, J.; Asano, M.; Yamaki, T.; Yoshida, M. Chemical and radiation crosslinked polymer electrolyte membranes prepared from radiation-grafted ETFE films for DMFC applications. J. Power Sources 2006, 158, 69-77. [CrossRef]

165. Yamaki, T.; Tsukada, J.; Asano, M.; Katakai, R.; Yoshida, M. Preparation of Highly Stable Ion Exchange Membranes by Radiation-Induced Graft Copolymerization of Styrene and Bis(vinyl phenyl)ethane Into Crosslinked Polytetrafluoroethylene Films. J. Fuel Cell Sci. Technol. 2007, 4, 56-64. [CrossRef]

166. MacDonald, R.J. Synthesis of Highly Cross-Linked Cation-Exchange Polymers from an Aqueous Solution. U.S. Patent No. 4,617,321, 14 October 1986.

167. Hodgdon, R.B.; MacDonald, R.J.; Alexander, S.A. High Ion Exchange Capacity Polyelectrolytes Having High Crosslink Densities and Caustic Stability. U.S. Patent No. 5,118,717, 2 June 1992.

168. Kamcev, J.; Paul, D.R.; Freeman, B.D. Effect of fixed charge group concentration on equilibrium ion sorption in ion exchange membranes. J. Mater. Chem. A 2017, 5, 4638-4650. [CrossRef]

169. Van Berchum, B.; Hessing, J.; Anthenis, H. Curable Compositions and Membranes. U.S. Patent No. 8,968,965, 3 March 2015.

170. Kamcev, J.; Doherty, C.M.; Lopez, K.P.; Hill, A.J.; Paul, D.R.; Freeman, B.D. Effect of fixed charge group concentration on salt permeability and diffusion coefficients in ion exchange membranes. J. Membr. Sci. 2018, 566, 307-316. [CrossRef]

171. Kamcev, J.; Paul, D.R.; Freeman, B.D. Equilibrium ion partitioning between aqueous salt solutions and inhomogeneous ion exchange membranes. Desalination 2018, 446, 31-41. [CrossRef]

172. Mukaddam, M.; Litwiller, E.; Pinnau, I. Gas Sorption, Diffusion, and Permeation in Nafion. Macromolecules 2016, 49, 280-286. [CrossRef]

173. Xu, T. Ion exchange membranes: State of their development and perspective. J. Membr. Sci. 2005, 263, 1-29. [CrossRef]

174. Bose, S.; Kuila, T.; Nguyen, T.X.H.; Kim, N.H.; Lau, K.; Lee, J.H. Polymer membranes for high temperature proton exchange membrane fuel cell: Recent advances and challenges. Prog. Polym. Sci. 2011, 36, 813-843. [CrossRef]

175. Esfahani, M.R.; Aktij, S.A.; Dabaghian, Z.; Firouzjaei, M.D.; Rahimpour, A.; Eke, J.; Escobar, I.C.; Abolhassani, M.; Greenlee, L.F.; Esfahani, A.R.; et al. Nanocomposite membranes for water separation and purification: Fabrication, modification, and applications. Sep. Purif. Technol. 2019, 213, 465-499. [CrossRef]

176. Yandrasits, M.A.; Lindell, M.J.; Hamrock, S.J. New directions in perfluoroalkyl sulfonic acid-based proton-exchange membranes. Curr. Opin. Electrochem. 2019, 18, 90-98. [CrossRef]

177. Karimi, M.B.; Mohammadi, F.; Hooshyari, K. Recent approaches to improve Nafion performance for fuel cell applications: A review. Int. J. Hydrogen Energy 2019, 44, 28919-28938. [CrossRef]

178. Yaroslavtsev, A.B.; Yampolskii, Y.P. Hybrid membranes containing inorganic nanoparticles. Mendeleev Commun. 2014, 24, 319-326. [CrossRef]

179. Wu, X.; Tian, Z.; Wang, S.; Peng, D.; Yang, L.; Wu, Y.; Xin, Q.; Wu, H.; Jiang, Z. Mixed matrix membranes comprising polymers of intrinsic microporosity and covalent organic framework for gas separation. J. Membr. Sci. 2017, 528, 273-283. [CrossRef]

180. Jiang, R.; Kunz, H.R.; Fenton, J.M. Composite silica/Nafion ${ }^{\circledR}$ membranes prepared by tetraethylorthosilicate sol-gel reaction and solution casting for direct methanol fuel cells. J. Membr. Sci. 2006, 272, 116-124. [CrossRef]

181. Wang, X.; Jin, M.; Li, Y.; Zhao, L. The influence of various ionic liquids on the properties of SPEEK membrane doped with mesoporous silica. Electrochim. Acta 2017, 257, 290-300. [CrossRef]

182. Voropaeva, E.Y.; Stenina, I.A.; Yaroslavtsev, A.B. Transport properties of hydrous-silica-modified MF-4SK membranes. Russ. J. Inorg. Chem. 2008, 53, 1531-1535. [CrossRef]

183. Sahu, A.K.; Meenakshi, S.; Bhat, S.D.; Shahid, A.; Sridhar, P.; Pitchumani, S.; Shukla, A.K. Meso-Structured Silica-Nafion Hybrid Membranes for Direct Methanol Fuel Cells. J. Electrochem. Soc. 2012, 159, F702-F710. [CrossRef]

184. Wang, Y.; Han, G.; Tian, Z.; Wang, M.; Li, J.; Wang, X. Nafion ${ }^{\circledR} / \mathrm{SiO}_{2} / \mathrm{m}$-BOT composite membranes for improved direct methanol fuel cell performance. RSC Adv. 2014, 4, 47129-47135. [CrossRef] 
185. Oh, K.; Kwon, O.; Son, B.; Lee, D.H.; Shanmugam, S. Nafion-sulfonated silica composite membrane for proton exchange membrane fuel cells under operating low humidity condition. J. Membr. Sci. 2019, 583, 103-109. [CrossRef]

186. Yang, C.-W.; Chen, C.-C.; Chen, K.-H.; Cheng, S. Effect of pore-directing agents in SBA-15 nanoparticles on the performance of Nafion ${ }^{\circledR} /$ SBA-15n composite membranes for DMFC. J. Membr. Sci. 2017, 526, 106-117. [CrossRef]

187. Wang, H.; Li, X.; Zhuang, X.; Cheng, B.; Wang, W.; Kang, W.; Shi, L.; Li, H. Modification of Nafion membrane with biofunctional $\mathrm{SiO}_{2}$ nanofiber for proton exchange membrane fuel cells. J. Power Sources 2017, 340, 201-209. [CrossRef]

188. Adjemian, K.T.; Dominey, R.; Krishnan, L.; Ota, H.; Majsztrik, P.; Zhang, T.; Mann, J.; Kirby, B.; Gatto, L.; Velo-Simpson, M.; et al. Function and Characterization of Metal Oxide-Nafion Composite Membranes for Elevated-Temperature $\mathrm{H}_{2} / \mathrm{O}_{2}$ PEM Fuel Cells. Chem. Mater. 2006, 18, 2238-2248. [CrossRef]

189. Patil, Y.; Mauritz, K.A. Durability enhancement of Nafion ${ }^{\circledR}$ fuel cell membranes via in situ sol-gel-derived titanium dioxide reinforcement. J. Appl. Polym. Sci. 2009, 113, 3269-3278. [CrossRef]

190. Saccà, A.; Gatto, I.; Carbone, A.; Pedicini, R.; Maisano, S.; Stassi, A.; Passalacqua, E. Influence of doping level in Yttria-Stabilised-Zirconia (YSZ) based-fillers as degradation inhibitors for proton exchange membranes fuel cells (PEMFCs) in drastic conditions. Int. J. Hydrogen Energy 2019, 44, 31445-31457. [CrossRef]

191. Vinothkannan, M.; Ramakrishnan, S.; Kim, A.R.; Lee, H.-K.; Yoo, D.J. Ceria Stabilized by Titanium Carbide as a Sustainable Filler in the Nafion Matrix Improves the Mechanical Integrity, Electrochemical Durability, and Hydrogen Impermeability of Proton-Exchange Membrane Fuel Cells: Effects of the Filler Content. ACS Appl. Mater. Interfaces 2020, 12, 5704-5716. [CrossRef]

192. D’Epifanio, A.; Navarra, M.A.; Weise, F.C.; Mecheri, B.; Farrington, J.; Licoccia, S.; Greenbaum, S. Composite Nafion/Sulfated Zirconia Membranes: Effect of the Filler Surface Properties on Proton Transport Characteristics. Chem. Mater. 2010, 22, 813-821. [CrossRef]

193. Di Noto, V.; Bettiol, M.; Bassetto, F.; Boaretto, N.; Negro, E.; Lavina, S.; Bertasi, F. Hybrid inorganic-organic nanocomposite polymer electrolytes based on Nafion and fluorinated $\mathrm{TiO}_{2}$ for PEMFCs. Int. J. Hydrogen Energy 2012, 37, 6169-6181. [CrossRef]

194. Matos, B.R.; Isidoro, R.A.; Santiago, E.I.; Fonseca, F.C. Performance enhancement of direct ethanol fuel cell using Nafion composites with high volume fraction of titania. J. Power Sources 2014, 268, 706-711. [CrossRef]

195. Ketpang, K.; Lee, K.; Shanmugam, S. Facile Synthesis of Porous Metal Oxide Nanotubes and Modified Nafion Composite Membranes for Polymer Electrolyte Fuel Cells Operated under Low Relative Humidity. ACS Appl. Mater. Interfaces 2014, 6, 16734-16744. [CrossRef] [PubMed]

196. Saccà, A.; Carbone, A.; Gatto, I.; Pedicini, R.; Freni, A.; Patti, A.; Passalacqua, E. Composites Nafion-titania membranes for Polymer Electrolyte Fuel Cell (PEFC) applications at low relative humidity levels: Chemical physical properties and electrochemical performance. Polym. Test. 2016, 56, 10-18. [CrossRef]

197. Taghizadeh, M.T.; Vatanparast, M. Ultrasonic-assisted synthesis of $\mathrm{ZrO}_{2}$ nanoparticles and their application to improve the chemical stability of Nafion membrane in proton exchange membrane (PEM) fuel cells. J. Colloid Interface Sci. 2016, 483, 1-10. [CrossRef] [PubMed]

198. Aziz, M.A.; Shanmugam, S. Ultra-high proton/vanadium selectivity of a modified sulfonated poly(arylene ether ketone) composite membrane for all vanadium redox flow batteries. J. Mater. Chem. A 2017, 5, 16663-16671. [CrossRef]

199. Gashoul, F.; Parnian, M.J.; Rowshanzamir, S. A new study on improving the physicochemical and electrochemical properties of SPEEK nanocomposite membranes for medium temperature proton exchange membrane fuel cells using different loading of zirconium oxide nanoparticles. Int. J. Hydrogen Energy 2017, 42, 590-602. [CrossRef]

200. Yaroslavtsev, A.B.; Karavanova, Y.A.; Safronova, E.Y. Ionic conductivity of hybrid membranes. Pet. Chem. 2011, 51, 473-479. [CrossRef]

201. Voropaeva, E.Y.; Sanginov, E.A.; Volkov, V.I.; Pavlov, A.A.; Shalimov, A.S.; Stenina, I.A.; Yaroslavtsev, A.B. Transport properties of MF-4SK membranes modified with inorganic dopants. Russ. J. Inorg. Chem. 2008, 53, 1536-1541. [CrossRef]

202. Wong, C.Y.; Wong, W.Y.; Ramya, K.; Khalid, M.; Loh, K.S.; Daud, W.R.W.; Lim, K.L.; Walvekar, R.; Kadhum, A.A.H. Additives in proton exchange membranes for low- and high-temperature fuel cell applications: A review. Int. J. Hydrogen Energy 2019, 44, 6116-6135. [CrossRef] 
203. Shaari, N.; Kamarudin, S.K. Recent advances in additive-enhanced polymer electrolyte membrane properties in fuel cell applications: An overview. Int. J. Energy Res. 2019, 43, 2756-2794. [CrossRef]

204. Volkov, V.I.; Chernyak, A.V.; Golubenko, D.V.; Shevlyakova, N.V.; Tverskoy, V.A.; Yaroslavtsev, A.B. Mobility of Cations and Water Molecules in Sulfocation-Exchange Membranes Based on Polyethylene and Sulfonated Grafted Polystyrene. Membr. Membr. Technol. 2020, 2, 54-62. [CrossRef]

205. Porozhnyy, M.; Huguet, P.; Cretin, M.; Safronova, E.; Nikonenko, V. Mathematical modeling of transport properties of proton-exchange membranes containing immobilized nanoparticles. Int. J. Hydrogen Energy 2016, 41, 15605-15614. [CrossRef]

206. Novikova, S.A.; Safronova, E.Y.; Lysova, A.A.; Yaroslavtsev, A.B. Influence of incorporated nanoparticles on the ionic conductivity of MF-4SC membrane. Mendeleev Commun. 2010, 20, 156-157. [CrossRef]

207. Lee, K.H.; Chu, J.Y.; Kim, A.R.; Yoo, D.J. Effect of functionalized $\mathrm{SiO}_{2}$ toward proton conductivity of composite membranes for PEMFC application. Int. J. Energy Res. 2019, 43, 5333-5345. [CrossRef]

208. Subianto, S.; Pica, M.; Casciola, M.; Cojocaru, P.; Merlo, L.; Hards, G.; Jones, D.J. Physical and chemical modification routes leading to improved mechanical properties of perfluorosulfonic acid membranes for PEM fuel cells. J. Power Sources 2013, 233, 216-230. [CrossRef]

209. Safronova, E.Y.; Bobreshova, O.V.; Garcia-Vasquez, W.; Yaroslavtsev, A.B. Relationships between water uptake, conductivity and mechanical properties of hybrid MF-4SC membranes doped by silica nanoparticles. Mendeleev Commun. 2015, 25, 54-55. [CrossRef]

210. Pereira, F.; Vallé, K.; Belleville, P.; Morin, A.; Lambert, S.; Sanchez, C. Advanced Mesostructured Hybrid Silica-Nafion Membranes for High-Performance PEM Fuel Cell. Chem. Mater. 2008, 20, 1710-1718. [CrossRef]

211. Li, J.; Xu, G.; Luo, X.; Xiong, J.; Liu, Z.; Cai, W. Effect of nano-size of functionalized silica on overall performance of swelling-filling modified Nafion membrane for direct methanol fuel cell application. Appl. Energy 2018, 213, 408-414. [CrossRef]

212. Simari, C.; Enotiadis, A.; Lo Vecchio, C.; Baglio, V.; Coppola, L.; Nicotera, I. Advances in hybrid composite membranes engineering for high-performance direct methanol fuel cells by alignment of 2D nanostructures and a dual-layer approach. J. Membr. Sci. 2020, 599, 117858. [CrossRef]

213. Park, J.-S.; Shin, M.-S.; Kim, C.-S. Proton exchange membranes for fuel cell operation at low relative humidity and intermediate temperature: An updated review. Curr. Opin. Electrochem. 2017, 5, 43-55. [CrossRef]

214. Ercelik, M.; Ozden, A.; Devrim, Y.; Colpan, C.O. Investigation of Nafion based composite membranes on the performance of DMFCs. Int. J. Hydrogen Energy 2017, 42, 2658-2668. [CrossRef]

215. Peng, K.-J.; Lai, J.-Y.; Liu, Y.-L. Nanohybrids of graphene oxide chemically-bonded with Nafion: Preparation and application for proton exchange membrane fuel cells. J. Membr. Sci. 2016, 514, 86-94. [CrossRef]

216. Tseng, C.-Y.; Ye, Y.-S.; Cheng, M.-Y.; Kao, K.-Y.; Shen, W.-C.; Rick, J.; Chen, J.-C.; Hwang, B.-J. Sulfonated Polyimide Proton Exchange Membranes with Graphene Oxide show Improved Proton Conductivity, Methanol Crossover Impedance, and Mechanical Properties. Adv. Energy Mater. 2011, 1, 1220-1224. [CrossRef]

217. Yin, Y.; Xu, T.; He, G.; Jiang, Z.; Wu, H. Fabrication of sulfonated poly(ether ether ketone)-based hybrid proton-conducting membranes containing carboxyl or amino acid-functionalized titania by in situ sol-gel process. J. Power Sources 2015, 276, 271-278. [CrossRef]

218. Safronova, E.Y.; Stenina, I.A.; Yaroslavtsev, A.B. Synthesis and characterization of $\mathrm{MF}-4 \mathrm{SK}+\mathrm{SiO}_{2}$ hybrid membranes modified with tungstophosphoric heteropolyacid. Russ. J. Inorg. Chem. 2010, 55, 13-17. [CrossRef]

219. Shao, Z.-G.; Joghee, P.; Hsing, I.-M. Preparation and characterization of hybrid Nafion-silica membrane doped with phosphotungstic acid for high temperature operation of proton exchange membrane fuel cells. J. Membr. Sci. 2004, 229, 43-51. [CrossRef]

220. Yu, E.; Prikhno, I.A.; Yu, G.; Andrey, B. Nanocomposite Membrane Materials Based on Nafion and Cesium Acid Salt of Phosphotungstic Heteropolyacid. Chem. Eng. 2015, 43, 679-684. [CrossRef]

221. Tian, N.; Wu, X.; Yang, B.; Wu, Q.; Cao, F.; Yan, W.; Yaroslavtsev, A.B. Proton-conductive membranes based on vanadium substituted heteropoly acids with Keggin structure and polymers. J. Appl. Polym. Sci. 2015, 132. [CrossRef]

222. Gerasimova, E.; Safronova, E.; Ukshe, A.; Dobrovolsky, Y.; Yaroslavtsev, A. Electrocatalytic and transport properties of hybrid Nafion ${ }^{\circledR}$ membranes doped with silica and cesium acid salt of phosphotungstic acid in hydrogen fuel cells. Chem. Eng. J. 2016, 305, 121-128. [CrossRef] 
223. Prikhno, I.A.; Yaroslavtsev, A.B.; Golubenko, D.V. Effect of Modification with Cesium Acid Salt of Phosphotungstic Acid on the Properties of Membranes Based on Grafted Sulfonated Polystyrene. Membr. Membr. Technol. 2019, 1,361-367. [CrossRef]

224. Xu, X.; Wang, H.; Lu, S.; Peng, S.; Xiang, Y. A phosphotungstic acid self-anchored hybrid proton exchange membrane for direct methanol fuel cells. RSC Adv. 2016, 6, 43049-43055. [CrossRef]

225. Prikhno, I.A.; Ivanova, K.A.; Don, G.M.; Yaroslavtsev, A.B. Hybrid membranes based on short side chain perfluorinated sulfonic acid membranes (Inion) and heteropoly acid salts. Mendeleev Commun. 2018, 28, 657-658. [CrossRef]

226. Wang, J.; Bai, H.; Zhang, H.; Zhao, L.; Chen, H.; Li, Y. Anhydrous proton exchange membrane of sulfonated poly(ether ether ketone) enabled by polydopamine-modified silica nanoparticles. Electrochim. Acta 2015, 152, 443-455. [CrossRef]

227. Amiinu, I.S.; Li, W.; Wang, G.; Tu, Z.; Tang, H.; Pan, M.; Zhang, H. Toward anhydrous proton conductivity based on imidazole functionalized mesoporous Silica/Nafion composite membranes. Electrochim. Acta 2015, 160, 185-194. [CrossRef]

228. Mikheev, A.G.; Safronova, E.Y.; Yurkov, G.Y.; Yaroslavtsev, A.B. Hybrid materials based on MF-4SC perfluorinated sulfo cation-exchange membranes and silica with proton-acceptor properties. Mendeleev Commun. 2013, 23, 66-68. [CrossRef]

229. Golubenko, D.V.; Shaydullin, R.R.; Yaroslavtsev, A.B. Improving the conductivity and permselectivity of ion-exchange membranes by introduction of inorganic oxide nanoparticles: Impact of acid-base properties. Colloid Polym. Sci. 2019, 297, 741-748. [CrossRef]

230. Yaroslavtsev, A.B. Ion exchange on inorganic sorbents. Russ. Chem. Rev. 1997, 66, 579-596. [CrossRef]

231. Atalay, S.; Ma, Y.; Qian, S. Analytical model for charge properties of silica particles. J. Colloid Interface Sci. 2014, 425, 128-130. [CrossRef]

232. Sonnefeld, J. On the influence of background electrolyte concentration on the position of the isoelectric point and the point of zero charge. Colloids Surf. A Physicochem. Eng. Asp. 2001, 190, 179-183. [CrossRef]

233. Nagarale, R.K.; Gohil, G.S.; Shahi, V.K.; Trivedi, G.S.; Rangarajan, R. Preparation and electrochemical characterization of cation- and anion-exchange/polyaniline composite membranes. J. Colloid Interface Sci. 2004, 277, 162-171. [CrossRef]

234. Yaroslavtsev, A.B.; Stenina, I.A.; Voropaeva, E.Y.; Ilyina, A.A. Ion transfer in composite membranes based on MF-4SC incorporating nanoparticles of silica, zirconia, and polyaniline. Polym. Adv. Technol. 2009, 20, 566-570. [CrossRef]

235. Hosseini, S.M.; Jeddi, F.; Nemati, M.; Madaeni, S.S.; Moghadassi, A.R. Electrodialysis heterogeneous anion exchange membrane modified by PANI/MWCNT composite nanoparticles: Preparation, characterization and ionic transport property in desalination. Desalination 2014, 341, 107-114. [CrossRef]

236. Loza, N.V.; Loza, S.A.; Kononenko, N.A.; Magalyanov, A.V. Ion Transport in sulfuric acid solution through anisotropic composites based on heterogeneous membranes and polyaniline. Pet. Chem. 2015, 55, 724-729. [CrossRef]

237. Liu, J.; Lai, L.; Sahoo, N.G.; Zhou, W.; Shen, Z.; Chan, S.H. Carbon Nanotube-Based Materials for Fuel Cell Applications. Aust. J. Chem. 2012, 65, 1213. [CrossRef]

238. Ijeri, V.; Cappelletto, L.; Bianco, S.; Tortello, M.; Spinelli, P.; Tresso, E. Nafion and carbon nanotube nanocomposites for mixed proton and electron conduction. J. Membr. Sci. 2010, 363, 265-270. [CrossRef]

239. Liu, Y.-L.; Su, Y.-H.; Chang, C.-M.; Wang, S.D.-M.; Lai, J.-Y. Preparation and applications of Nafion-functionalized multiwalled carbon nanotubes for proton exchange membrane fuel cells. J. Mater. Chem. 2010, 20, 4409. [CrossRef]

240. Prikhno, I.A.; Safronova, E.Y.; Yaroslavtsev, A.B. Hybrid materials based on perfluorosulfonic acid membrane and functionalized carbon nanotubes: Synthesis, investigation and transport properties. Int. J. Hydrogen Energy 2016, 41, 15585-15592. [CrossRef]

241. Janghorban, K.; Molla-Abbasi, P. Modified CNTs/Nafion composite: The role of sulfonate groups on the performance of prepared proton exchange methanol fuel cell's membrane. J. Part Sci. Technol. 2017, 3, 211-218. [CrossRef]

242. Yin, C.; Li, J.; Zhou, Y.; Zhang, H.; Fang, P.; He, C. Enhancement in Proton Conductivity and Thermal Stability in Nafion Membranes Induced by Incorporation of Sulfonated Carbon Nanotubes. ACS Appl. Mater. Interfaces 2018, 10, 14026-14035. [CrossRef] 
243. Chang, S.C.-M.; Liu, Y.-L.; Lee, Y.M. Polybenzimidazole membranes modified with polyelectrolyte-functionalized multiwalled carbon nanotubes for proton exchange membrane fuel cells. J. Mater. Chem. 2011, 21, 7480-7486. [CrossRef]

244. Yun, S.; Im, H.; Heo, Y.; Kim, J. Crosslinked sulfonated poly(vinyl alcohol)/sulfonated multi-walled carbon nanotubes nanocomposite membranes for direct methanol fuel cells. J. Membr. Sci. 2011, 380, 208-215. [CrossRef]

245. Avilés-Barreto, S.L.; Suleiman, D. Effect of single-walled carbon nanotubes on the transport properties of sulfonated poly(styrene-isobutylene-styrene) membranes. J. Membr. Sci. 2015, 474, 92-102. [CrossRef]

246. Cui, L.; Geng, Q.; Gong, C.; Liu, H.; Zheng, G.; Wang, G.; Liu, Q.; Wen, S. Novel sulfonated poly (ether ether ketone)/silica coated carbon nanotubes high-performance composite membranes for direct methanol fuel cell. Polym. Adv. Technol. 2015, 26, 457-464. [CrossRef]

247. Molla-Abbasi, P.; Asgari, M.S.; Sadrabadi, M.M.H. Improving the Performance of Nafion ${ }^{\circledR}$-Based Fuel Cell Membranes by Introducing Histidine Functionalized Carbon Nanotubes. J. Macromol. Sci. Part B 2017, 56, 234-244. [CrossRef]

248. Tohidian, M.; Ghaffarian, S.R. Surface modified multi-walled carbon nanotubes and Nafion nanocomposite membranes for use in fuel cell applications. Polym. Adv. Technol. 2018, 29, 1219-1226. [CrossRef]

249. Wang, L.; Kang, J.; Nam, J.-D.; Suhr, J.; Prasad, A.K.; Advani, S.G. Composite Membrane Based on Graphene Oxide Sheets and Nafion for Polymer Electrolyte Membrane Fuel Cells. ECS Electrochem. Lett. 2014, 4, F1-F4. [CrossRef]

250. Asmatulu, R.; Khan, A.; Adigoppula, V.K.; Hwang, G. Enhanced transport properties of graphene-based, thin Nafion ${ }^{\circledR}$ membrane for polymer electrolyte membrane fuel cells. Int. J. Energy Res. 2018, 42, 508-519. [CrossRef]

251. Lin, C.W.; Lu, Y.S. Highly ordered graphene oxide paper laminated with a Nafion membrane for direct methanol fuel cells. J. Power Sources 2013, 237, 187-194. [CrossRef]

252. Sahu, A.K.; Ketpang, K.; Shanmugam, S.; Kwon, O.; Lee, S.; Kim, H. Sulfonated Graphene-Nafion Composite Membranes for Polymer Electrolyte Fuel Cells Operating under Reduced Relative Humidity. J. Phys. Chem. C 2016, 120, 15855-15866. [CrossRef]

253. Vinothkannan, M.; Kim, A.R.; Kumar, G.G.; Yoo, D.J. Sulfonated graphene oxide/Nafion composite membranes for high temperature and low humidity proton exchange membrane fuel cells. RSC Adv. 2018, 8, 7494-7508. [CrossRef]

254. Ariono, D.; Wenten, I.G. Surface modification of ion-exchange membranes: Methods, characteristics, and performance. J. Appl. Polym. Sci. 2017, 134, 45540. [CrossRef]

255. Zabolotskii, V.I.; Loza, S.A.; Sharafan, M.V. Physicochemical Properties of Profiled Heterogeneous Ion-Exchange Membranes. Russ. J. Electrochem. 2005, 41, 1053-1060. [CrossRef]

256. Vasil'eva, V.I.; Goleva, E.A. Selective separation of sodium ions from a mixture with phenylalanine by Donnan dialysis with a profiled sulfogroup cation exchange membrane. Russ. J. Phys. Chem. A 2013, 87, 1895-1901. [CrossRef]

257. Loza, S.A.; Zabolotsky, V.I.; Loza, N.V.; Fomenko, M.A. Structure, morphology, and transport characteristics of profiled bilayer membranes. Pet. Chem. 2016, 56, 1027-1033. [CrossRef]

258. Pawlowski, S.; Rijnaarts, T.; Saakes, M.; Nijmeijer, K.; Crespo, J.G.; Velizarov, S. Improved fluid mixing and power density in reverse electrodialysis stacks with chevron-profiled membranes. J. Membr. Sci. 2017, 531, 111-121. [CrossRef]

259. Pawlowski, S.; Crespo, J.G.; Velizarov, S. Profiled Ion Exchange Membranes: A Comprehensible Review. Int. J. Mol. Sci. 2019, 20, 165. [CrossRef] [PubMed]

260. Vasil'eva, V.; Goleva, E.; Pismenskaya, N.; Kozmai, A.; Nikonenko, V. Effect of surface profiling of a cation-exchange membrane on the phenylalanine and $\mathrm{NaCl}$ separation performances in diffusion dialysis. Sep. Purif. Technol. 2019, 210, 48-59. [CrossRef]

261. Vasil'eva, V.I.; Kranina, N.A.; Malykhin, M.D.; Akberova, E.M.; Zhiltsova, A.V. The surface inhomogeneity of ion-exchange membranes by SEM and AFM data. J. Surf. Investig. X-ray Synchrotron Neutron Tech. 2013, 7, 144-153. [CrossRef]

262. Vermaas, D.A.; Saakes, M.; Nijmeijer, K. Power generation using profiled membranes in reverse electrodialysis. J. Membr. Sci. 2011, 385, 234-242. [CrossRef] 
263. Melnikov, S.; Loza, S.; Sharafan, M.; Zabolotskiy, V. Electrodialysis treatment of secondary steam condensate obtained during production of ammonium nitrate. Technical and economic analysis. Sep. Purif. Technol. 2016, 157, 179-191. [CrossRef]

264. Battaglia, G.; Gurreri, L.; Farulla, G.A.; Cipollina, A.; Pirrotta, A.; Micale, G.; Ciofalo, M. Membrane Deformation and Its Effects on Flow and Mass Transfer in the Electromembrane Processes. Int. J. Mol. Sci. 2019, 20, 1840. [CrossRef] [PubMed]

265. Larchet, C.; Zabolotsky, V.I.; Pismenskaya, N.; Nikonenko, V.V.; Tskhay, A.; Tastanov, K.; Pourcelly, G. Comparison of different ED stack conceptions when applied for drinking water production from brackish waters. Desalination 2008, 222, 489-496. [CrossRef]

266. Kir, E.; Gurler, B.; Gulec, A. Boron removal from aqueous solution by using plasma-modified and unmodified anion-exchange membranes. Desalination 2011, 267, 114-117. [CrossRef]

267. Choi, W.C.; Kim, J.D.; Woo, S.I. Modification of proton conducting membrane for reducing methanol crossover in a direct-methanol fuel cell. J. Power Sources 2001, 96, 411-414. [CrossRef]

268. Lee, J.-S.; Hwang, I.-T.; Jung, C.-H.; Choi, J.-H. Surface modification of Nafion membranes by ion implantation to reduce methanol crossover in direct methanol fuel cells. RSC Adv. 2016, 6, 62467-62470. [CrossRef]

269. Lue, S.J.; Hsiaw, S.-Y.; Wei, T.-C. Surface modification of perfluorosulfonic acid membranes with perfluoroheptane (C7F16)/argon plasma. J. Membr. Sci. 2007, 305, 226-237. [CrossRef]

270. Abdrashitov, E.F.; Bokun, V.C.; Dobrovolsky, Y.A.; Kritskaya, D.A.; Sanginov, E.A.; Ponomarev, A.N. Modification of the proton conducting membranes of MF-4SC with a carbon phase via gamma-initiated graft polymerization of vinyliden chloride. Solid State Ion. 2011, 188, 140-143. [CrossRef]

271. Filippov, A.; Afonin, D.; Kononenko, N.; Shkirskaya, S. Characterization of Perfluorinated Cation-Exchange Membranes MF-4SC Surface Modified with Halloysite Nanotubes. In AIP Conference Proceedings, Proceedings of the AIP Conference, Albena, Bulgaria, 28 October 2015; M.D., T., Ed.; American Institute of Physics Inc.: Moscow, Russia, 2015; Volume 1684, p. 030004.

272. Pismenskaya, N.; Melnik, N.; Nevakshenova, E.; Nebavskaya, K.; Nikonenko, V. Enhancing Ion Transfer in Overlimiting Electrodialysis of Dilute Solutions by Modifying the Surface of Heterogeneous Ion-Exchange Membranes. Int. J. Chem. Eng. 2012, 2012, 528290. [CrossRef]

273. Zabolotskii, V.I.; Chermit, R.K.; Sharafan, M.V. Mass transfer mechanism and chemical stability of strongly basic anion-exchange membranes under overlimiting current conditions. Russ. J. Electrochem. 2014, 50, 38-45. [CrossRef]

274. Sharafan, M.V.; Zabolotskii, V.I.; Bugakov, V.V. Electric mass transport through homogeneous and surface-modified heterogeneous ion-exchange membranes at a rotating membrane disk. Russ. J. Electrochem. 2009, 45, 1162. [CrossRef]

275. Belashova, E.D.; Melnik, N.A.; Pismenskaya, N.D.; Shevtsova, K.A.; Nebavsky, A.V.; Lebedev, K.A.; Nikonenko, V.V. Overlimiting mass transfer through cation-exchange membranes modified by Nafion film and carbon nanotubes. Electrochim. Acta 2012, 59, 412-423. [CrossRef]

276. Andreeva, M.A.; Gil, V.V.; Pismenskaya, N.D.; Nikonenko, V.V.; Dammak, L.; Larchet, C.; Grande, D.; Kononenko, N.A. Effect of homogenization and hydrophobization of a cation-exchange membrane surface on its scaling in the presence of calcium and magnesium chlorides during electrodialysis. J. Membr. Sci. 2017, 540, 183-191. [CrossRef]

277. Andreeva, M.A.; Gil, V.V.; Pismenskaya, N.D.; Dammak, L.; Kononenko, N.A.; Larchet, C.; Grande, D.; Nikonenko, V.V. Mitigation of membrane scaling in electrodialysis by electroconvection enhancement, $\mathrm{pH}$ adjustment and pulsed electric field application. J. Membr. Sci. 2018, 549, 129-140. [CrossRef]

278. Pismenskaya, N.D.; Belova, E.I.; Nikonenko, V.V.; Zabolotsky, V.I.; Lopatkova, G.Y.; Karzhavin, Y.N.; Larchet, $\mathrm{C}$. Lower rate of $\mathrm{H}^{+}\left(\mathrm{OH}^{-}\right)$ions generation at an anion-exchange membrane in electrodialysis. Desalin. Water Treat. 2010, 21, 109-114. [CrossRef]

279. Tanaka, Y. Water Dissociation. In Membrane Science and Technology; Elsevier: Amsterdam, The Netherlands, 2007; Volume 12, Chapter 8; pp. 139-186. ISBN 9780444519825.

280. Karavanova, Y.A.; Kas'kova, Z.M.; Veresov, A.G.; Yaroslavtsev, A.B. Diffusion properties of bilayer membranes based on MC-40 and MF-4SC modified with silicon and zirconium oxides. Russ. J. Inorg. Chem. 2010, 55, 479-483. [CrossRef]

281. Sata, T.; Sata, T.; Yang, W. Studies on cation-exchange membranes having permselectivity between cations in electrodialysis. J. Membr. Sci. 2002, 206, 31-60. [CrossRef] 
282. Firdaous, L.; Malériat, J.-P.; Schlumpf, J.-P.; Quéméneur, F. Transfer of Monovalent and Divalent Cations in Salt Solutions by Electrodialysis. Sep. Sci. Technol. 2007, 42, 931-948. [CrossRef]

283. White, W.; Sanborn, C.D.; Fabian, D.M.; Ardo, S. Conversion of Visible Light into Ionic Power Using Photoacid-Dye-Sensitized Bipolar Ion-Exchange Membranes. Joule 2018, 2, 94-109. [CrossRef]

284. Vermaas, D.A.; Smith, W.A. Synergistic Electrochemical $\mathrm{CO}_{2}$ Reduction and Water Oxidation with a Bipolar Membrane. ACS Energy Lett. 2016, 1, 1143-1148. [CrossRef]

285. Vermaas, D.A.; Sassenburg, M.; Smith, W.A. Photo-assisted water splitting with bipolar membrane induced $\mathrm{pH}$ gradients for practical solar fuel devices. J. Mater. Chem. A 2015, 3, 19556-19562. [CrossRef]

286. Vermaas, D.A.; Wiegman, S.; Nagaki, T.; Smith, W.A. Ion transport mechanisms in bipolar membranes for (photo)electrochemical water splitting. Sustain. Energy Fuels 2018, 2, 2006-2015. [CrossRef]

287. McDonald, M.B.; Bruce, J.P.; McEleney, K.; Freund, M.S. Reduced Graphene Oxide Bipolar Membranes for Integrated Solar Water Splitting in Optimal pH. ChemSusChem 2015, 8, 2645-2654. [CrossRef] [PubMed]

288. Chabi, S.; Wright, A.G.; Holdcroft, S.; Freund, M.S. Transparent Bipolar Membrane for Water Splitting Applications. ACS Appl. Mater. Interfaces 2017, 9, 26749-26755. [CrossRef] [PubMed]

289. Yan, Z.; Zhu, L.; Li, Y.C.; Wycisk, R.J.; Pintauro, P.N.; Hickner, M.A.; Mallouk, T.E. The balance of electric field and interfacial catalysis in promoting water dissociation in bipolar membranes. Energy Environ. Sci. 2018, 11, 2235-2245. [CrossRef]

290. Xu, T.; Yang, W. Fundamental studies on a novel series of bipolar membranes prepared from poly(2,6-dimethyl-1,4-phenylene oxide) (PPO) I. Effect of anion exchange layers on I-V curves of bipolar membranes. J. Membr. Sci. 2004, 238, 123-129. [CrossRef]

291. Xu, T. Development of bipolar membrane-based processes. Desalination 2001, 140, 247-258. [CrossRef]

292. Zhang, X.; Li, C.; Wang, Y.; Luo, J.; Xu, T. Recovery of acetic acid from simulated acetaldehyde wastewaters: Bipolar membrane electrodialysis processes and membrane selection. J. Membr. Sci. 2011, 379, 184-190. [CrossRef]

293. Han, J.-H.; Jeong, N.; Kim, C.-S.; Hwang, K.S.; Kim, H.; Nam, J.-Y.; Jwa, E.; Yang, S.; Choi, J. Reverse electrodialysis (RED) using a bipolar membrane to suppress inorganic fouling around the cathode. Water Res. 2019, 166, 115078. [CrossRef]

294. Xia, J.; Eigenberger, G.; Strathmann, H.; Nieken, U. Flow battery based on reverse electrodialysis with bipolar membranes: Single cell experiments. J. Membr. Sci. 2018, 565, 157-168. [CrossRef]

295. Titorova, V.; Sabbatovskiy, K.; Sarapulova, V.; Kirichenko, E.; Sobolev, V.; Kirichenko, K. Characterization of MK-40 Membrane Modified by Layers of Cation Exchange and Anion Exchange Polyelectrolytes. Membranes (Basel) 2020, 10, 20. [CrossRef]

296. Xu, X.; Lin, L.; Ma, G.; Wang, H.; Jiang, W.; He, Q.; Nirmalakhandan, N.; Xu, P. Study of polyethyleneimine coating on membrane permselectivity and desalination performance during pilot-scale electrodialysis of reverse osmosis concentrate. Sep. Purif. Technol. 2018, 207, 396-405. [CrossRef]

297. Jiang, W.; Lin, L.; Xu, X.; Wang, H.; Xu, P. Physicochemical and electrochemical characterization of cation-exchange membranes modified with polyethyleneimine for elucidating enhanced monovalent permselectivity of electrodialysis. J. Membr. Sci. 2019, 572, 545-556. [CrossRef]

298. Zhao, Y.; Tang, K.; Liu, Q.; Van der Bruggen, B.; Díaz, A.S.; Pan, J.; Gao, C.; Shen, J. Recovery of chemically degraded polyethyleneimine by a re-modification method: Prolonging the lifetime of cation exchange membranes. RSC Adv. 2016, 6, 16548-16554. [CrossRef]

299. Amara, M.; Kerdjoudj, H. Modification of cation-exchange membrane properties by electro-adsorption of polyethyleneimine. Desalination 2003, 155, 79-87. [CrossRef]

300. Le, X.T.; Viel, P.; Jégou, P.; Garcia, A.; Berthelot, T.; Bui, T.H.; Palacin, S. Diazonium-induced anchoring process: An application to improve the monovalent selectivity of cation exchange membranes. J. Mater. Chem. 2010, 20, 3750-3757. [CrossRef]

301. Sivaraman, P.; Chavan, J.G.; Thakur, A.P.; Hande, V.R.; Samui, A.B. Electrochemical modification of cation exchange membrane with polyaniline for improvement in permselectivity. Electrochim. Acta 2007, 52, 5046-5052. [CrossRef]

302. Malik, M.S.; Qaiser, A.A.; Arif, M.A. Structural and electrochemical studies of heterogeneous ion exchange membranes based on polyaniline-coated cation exchange resin particles. RSC Adv. 2016, 6, 115046-115054. [CrossRef] 
303. Kumar, M.; Khan, M.A.; AlOthman, Z.A.; Siddiqui, M.R. Polyaniline modified organic-inorganic hybrid cation-exchange membranes for the separation of monovalent and multivalent ions. Desalination 2013, 325, 95-103. [CrossRef]

304. Lysova, A.A.; Stenina, I.A.; Gorbunova, Y.G.; Yaroslavtsev, A.B. Preparation of MF-4SC composite membranes with the anisotropic distribution of polyaniline and ion-transport asymmetry. Polym. Sci. Ser. B 2011, 53, 35-41. [CrossRef]

305. Osipov, A.K.; Volkov, A.O.; Safronova, E.Y.; Yaroslavtsev, A.B. Ion transfer asymmetry in Nafion membranes with gradient distribution of acid salts of heteropoly acids. Russ. J. Inorg. Chem. 2017, 62, 723-728. [CrossRef]

306. Sata, T. Studies on anion exchange membranes having permselectivity for specific anions in electrodialysis-Effect of hydrophilicity of anion exchange membranes on permselectivity of anions. J. Membr. Sci. 2000, 167, 1-31. [CrossRef]

307. Hu, Y.; Wang, M.; Wang, D.; Gao, X.; Gao, C. Feasibility study on surface modification of cation exchange membranes by quaternized chitosan for improving its selectivity. J. Membr. Sci. 2008, 319, 5-9. [CrossRef]

308. Wang, M.; Jia, Y.; Yao, T.; Wang, K. The endowment of monovalent selectivity to cation exchange membrane by photo-induced covalent immobilization and self-crosslinking of chitosan. J. Membr. Sci. 2013, 442, $39-47$. [CrossRef]

309. Wang, W.; Liu, R.; Tan, M.; Sun, H.; Niu, Q.J.; Xu, T.; Nikonenko, V.; Zhang, Y. Evaluation of the ideal selectivity and the performance of selectrodialysis by using TFC ion exchange membranes. J. Membr. Sci. 2019, 582, 236-245. [CrossRef]

310. Jiang, C.; Zhang, D.; Muhammad, A.S.; Hossain, M.M.; Ge, Z.; He, Y.; Feng, H.; Xu, T. Fouling deposition as an effective approach for preparing monovalent selective membranes. J. Membr. Sci. 2019, 580, 327-335. [CrossRef]

311. Hosseini, S.M.; Madaeni, S.S.; Asiani, H.; Heidari, A.R. Preparation and Electrochemical Characterization of Monovalent Ion Selective Poly (Vinyl Chloride)-Blend-Poly (Styrene-Co-Butadiene) Heterogeneous Cation Exchange Membrane Coated with Poly (Methyl Methacrylate). Sep. Sci. Technol. 2012, 47, 1443-1454. [CrossRef]

312. Vaselbehagh, M.; Karkhanechi, H.; Takagi, R.; Matsuyama, H. Surface modification of an anion exchange membrane to improve the selectivity for monovalent anions in electrodialysis-experimental verification of theoretical predictions. J. Membr. Sci. 2015, 490, 301-310. [CrossRef]

313. Xue, L.; Gao, C.; Ruan, H.; Tang, K.; Zhao, Y.; Van der Bruggen, B.; Shen, J. Sulfonated reduced graphene oxide modification layers to improve monovalent anions selectivity and controllable resistance of anion exchange membrane. J. Membr. Sci. 2017, 536, 167-175. [CrossRef]

314. Pan, J.; Ding, J.; Tan, R.; Chen, G.; Zhao, Y.; Gao, C.; der Bruggen, B.; Van Shen, J. Preparation of a monovalent selective anion exchange membrane through constructing a covalently crosslinked interface by electro-deposition of polyethyleneimine. J. Membr. Sci. 2017, 539, 263-272. [CrossRef]

315. Krasemann, L.; Tieke, B. Selective Ion Transport across Self-Assembled Alternating Multilayers of Cationic and Anionic Polyelectrolytes. Langmuir 2000, 16, 287-290. [CrossRef]

316. Evdochenko, E.; Kamp, J.; Femmer, R.; Xu, Y.; Nikonenko, V.; Wessling, M. Unraveling the effect of charge distribution in a polyelectrolyte multilayer nanofiltration membrane on its ion transport properties. J. Membr. Sci. 2020, 611, 118045. [CrossRef]

317. Femmer, R.; Mani, A.; Wessling, M. Ion transport through electrolyte/polyelectrolyte multi-layers. Sci. Rep. 2015, 5, 11583. [CrossRef] [PubMed]

318. Cheng, C.; White, N.; Shi, H.; Robson, M.; Bruening, M.L. Cation separations in electrodialysis through membranes coated with polyelectrolyte multilayers. Polymer (Guildf) 2014, 55, 1397-1403. [CrossRef]

319. Abdu, S.; Martí-Calatayud, M.-C.; Wong, J.E.; García-Gabaldón, M.; Wessling, M. Layer-by-Layer Modification of Cation Exchange Membranes Controls Ion Selectivity and Water Splitting. ACS Appl. Mater. Interfaces 2014, 6, 1843-1854. [CrossRef]

320. White, N.; Misovich, M.; Yaroshchuk, A.; Bruening, M.L. Coating of Nafion membranes with polyelectrolyte multilayers to achieve high monovalent/divalent cation electrodialysis selectivities. ACS Appl. Mater. Interfaces 2015, 7, 6620-6628. [CrossRef]

321. Zhu, Y.; Ahmad, M.; Yang, L.; Misovich, M.; Yaroshchuk, A.; Bruening, M.L. Adsorption of polyelectrolyte multilayers imparts high monovalent/divalent cation selectivity to aliphatic polyamide cation-exchange membranes. J. Membr. Sci. 2017, 537, 177-185. [CrossRef] 
322. Afsar, N.U.; Shehzad, M.A.; Irfan, M.; Emmanuel, K.; Sheng, F.; Xu, T.; Ren, X.; Ge, L.; Xu, T. Cation exchange membrane integrated with cationic and anionic layers for selective ion separation via electrodialysis. Desalination 2019, 458, 25-33. [CrossRef]

323. Rijnaarts, T.; Reurink, D.M.; Radmanesh, F.; de Vos, W.M.; Nijmeijer, K. Layer-by-layer coatings on ion exchange membranes: Effect of multilayer charge and hydration on monovalent ion selectivities. J. Membr. Sci. 2019, 570, 513-521. [CrossRef]

324. Ahmad, M.; Tang, C.; Yang, L.; Yaroshchuk, A.; Bruening, M.L. Layer-by-layer modification of aliphatic polyamide anion-exchange membranes to increase $\mathrm{Cl}^{-} / \mathrm{SO}_{4}{ }^{2-}$ selectivity. J. Membr. Sci. 2019, 578, $209-219$. [CrossRef]

325. Zhao, Y.; Zhu, J.; Ding, J.; Van der Brugge, B.; Shen, J.; Gao, C. Electric-pulse layer-by-layer assembled of anion exchange membrane with enhanced monovalent selectivity. J. Membr. Sci. 2018, 548, 81-90. [CrossRef]

326. White, N.; Misovich, M.; Alemayehu, E.; Yaroshchuk, A.; Bruening, M.L. Highly selective separations of multivalent and monovalent cations in electrodialysis through Nafion membranes coated with polyelectrolyte multilayers. Polymer (Guildf) 2016, 103, 478-485. [CrossRef]

327. Kazemabad, M.; Verliefde, A.; Cornelissen, E.R.; D’Haese, A. Crown ether containing polyelectrolyte multilayer membranes for lithium recovery. J. Membr. Sci. 2020, 595, 117432. [CrossRef]

328. Golubenko, D.; Yaroslavtsev, A. Development of surface-sulfonated graft anion-exchange membranes with monovalent ion selectivity and antifouling properties for electromembrane processes. J. Membr. Sci. 2020, 612, 118408. [CrossRef]

329. Nikonenko, V.V.; Zabolotskii, V.V.; Lebedev, K.A. Model for the competitive transport of ions through ion exchange membranes with a modified surface. Russ. J. Electrochem. 1996, 32, 234-236.

330. Zabolotsky, V.I.; Manzanares, J.A.; Nikonenko, V.V.; Lebedev, K.A.; Lovtsov, E.G. Space charge effect on competitive ion transport through ion-exchange membranes. Desalination 2002, 147, 387-392. [CrossRef]

331. Zhang, Y.; Pinoy, L.; Meesschaert, B.; Van der Bruggen, B. Separation of small organic ions from salts by ion-exchange membrane in electrodialysis. AIChE J. 2011, 57, 2070-2078. [CrossRef]

332. Fíla, V.; Bouzek, K. A mathematical model of multiple ion transport across an ion-selective membrane under current load conditions. J. Appl. Electrochem. 2003, 33, 675-684. [CrossRef]

333. Zhang, W.; Miao, M.; Pan, J.; Sotto, A.; Shen, J.; Gao, C.; Van der Bruggen, B. Separation of divalent ions from seawater concentrate to enhance the purity of coarse salt by electrodialysis with monovalent-selective membranes. Desalination 2017, 411, 28-37. [CrossRef]

334. Noskov, S.Y.; Bernèche, S.; Roux, B. Control of ion selectivity in potassium channels by electrostatic and dynamic properties of carbonyl ligands. Nature 2004, 431, 830-834. [CrossRef]

335. Hatakeyama, E.S.; Gabriel, C.J.; Wiesenauer, B.R.; Lohr, J.L.; Zhou, M.; Noble, R.D.; Gin, D.L. Water filtration performance of a lyotropic liquid crystal polymer membrane with uniform, sub-1-nm pores. J. Membr. Sci. 2011, 366, 62-72. [CrossRef]

336. Wang, P.; Wang, M.; Liu, F.; Ding, S.; Wang, X.; Du, G.; Liu, J.; Apel, P.; Kluth, P.; Trautmann, C.; et al. Ultrafast ion sieving using nanoporous polymeric membranes. Nat. Commun. 2018, 9, 569. [CrossRef] [PubMed]

337. He, Y.; Ge, L.; Ge, Z.; Zhao, Z.; Sheng, F.; Liu, X.; Ge, X.; Yang, Z.; Fu, R.; Liu, Z.; et al. Monovalent cations permselective membranes with zwitterionic side chains. J. Membr. Sci. 2018, 563, 320-325. [CrossRef]

338. Oren, Y.; Litan, A. State of the solution-membrane interface during ion transport across an ion-exchange membrane. J. Phys. Chem. 1974, 78, 1805-1811. [CrossRef]

339. Geraldes, V.; Afonso, M.D. Limiting current density in the electrodialysis of multi-ionic solutions. J. Membr. Sci. 2010, 360, 499-508. [CrossRef]

340. Fíla, V.; Bouzek, K. The effect of convection in the external diffusion layer on the results of a mathematical model of multiple ion transport across an ion-selective membrane. J. Appl. Electrochem. 2008, 38, 1241-1252. [CrossRef]

(C) 2020 by the authors. Licensee MDPI, Basel, Switzerland. This article is an open access article distributed under the terms and conditions of the Creative Commons Attribution (CC BY) license (http://creativecommons.org/licenses/by/4.0/). 